OPEN ACCESS

Edited by:

Alejandra Vanina Volpedo, University of Buenos Aires, Argentina

Reviewed by:

Audrey J. Geffen,

University of Bergen, Norway

Guido Plaza,

Pontificia Universidad Católica de Valparaíso, Chile

*Correspondence:

Troy A. Rogers

troy.rogers@adelaide.edu.au

Specialty section:

This article was submitted to

Marine Ecosystem Ecology,

a section of the journal

Frontiers in Marine Science

Received: 27 August 2019

Accepted: 05 November 2019

Published: 27 November 2019

Citation:

Rogers TA, Fowler AJ, Steer MA

and Gillanders BM (2019)

Discriminating Natal Source Populations of a Temperate Marine Fish Using Larval Otolith Chemistry.

Front. Mar. Sci. 6:711. doi: 10.3389/fmars.2019.00711

\section{Discriminating Natal Source Populations of a Temperate Marine Fish Using Larval Otolith Chemistry}

\author{
Troy A. Rogers ${ }^{1,2 *}$, Anthony J. Fowler ${ }^{2}$, Michael A. Steer ${ }^{2}$ and Bronwyn M. Gillanders ${ }^{1}$ \\ ' Southern Seas Ecology Laboratories, School of Biological Sciences, The University of Adelaide, Adelaide, SA, Australia, \\ ${ }^{2}$ South Australian Research and Development Institute - Aquatic Sciences, Henley Beach, SA, Australia
}

The life cycles of many marine species depend on a dispersive larval stage that connects spatially segregated populations. However, quantifying larval movement among populations remains one of the greatest challenges in marine ecology. Such movement determines whether a population is essentially a self-recruiting stock, or if it forms part of a larger meta-population where recruits originate from multiple sources. Previous research has struggled to differentiate between such stock structure models for King George whiting (Sillaginodes punctatus; Perciformes) in southern Australia, largely due to difficulties in identifying the source populations of dispersing larvae. In this study, pelagic larvae were collected throughout the only recognized spawning area in South Australia in 2017 and 2018. First, we identified that the distribution of larvae was broadly divisible into two groups - those in southern Spencer Gulf and those in Investigator Strait. Then, the incremental structure and elemental composition of otoliths of larvae from the two regions were compared to determine if they had originated from a common source population. There were no spatial differences in the sizes (3.0-5.0 mm SL), ages (5-21 days), hatch dates (April 7-24) or average growth rates $\left(0.09-0.21 \mathrm{~mm} \mathrm{~d}^{-1}\right.$ ) of larvae. However, multi-elemental ( $\mathrm{Li}, \mathrm{Mg}, \mathrm{Mn}, \mathrm{Sr}$, and $\mathrm{Ba}$ ) otolith signatures differed significantly between the two regions, primarily driven by differences in concentrations of $\mathrm{Li}$ and $\mathrm{Ba}$. Although otolith signatures were year-specific, larvae were assigned to their region of capture with $70-82 \%$ accuracy. Larvae in each region hatched at the same time yet had significantly different otolith chemistry, providing strong evidence that those in southern Spencer Gulf and Investigator Strait originated from spatially segregated water masses. This study has demonstrated the ability of otolith chemistry to discriminate source populations of pelagic larvae in a fully marine environment, which provides a basis to quantify larval movement between fish populations.

Keywords: larvae, connectivity, otolith chemistry, microstructure, LA-ICP-MS, early life history, lithium, King George whiting

\section{INTRODUCTION}

Many marine species conform to a bipartite life cycle whereby spawning grounds and nursery areas are spatially segregated, and larval transport is an obligate process that connects life history stages (Cowen et al., 2000). The dispersal of larvae in marine environments is heavily influenced by physical oceanographic processes, which results in a high probability of mixing between larvae 


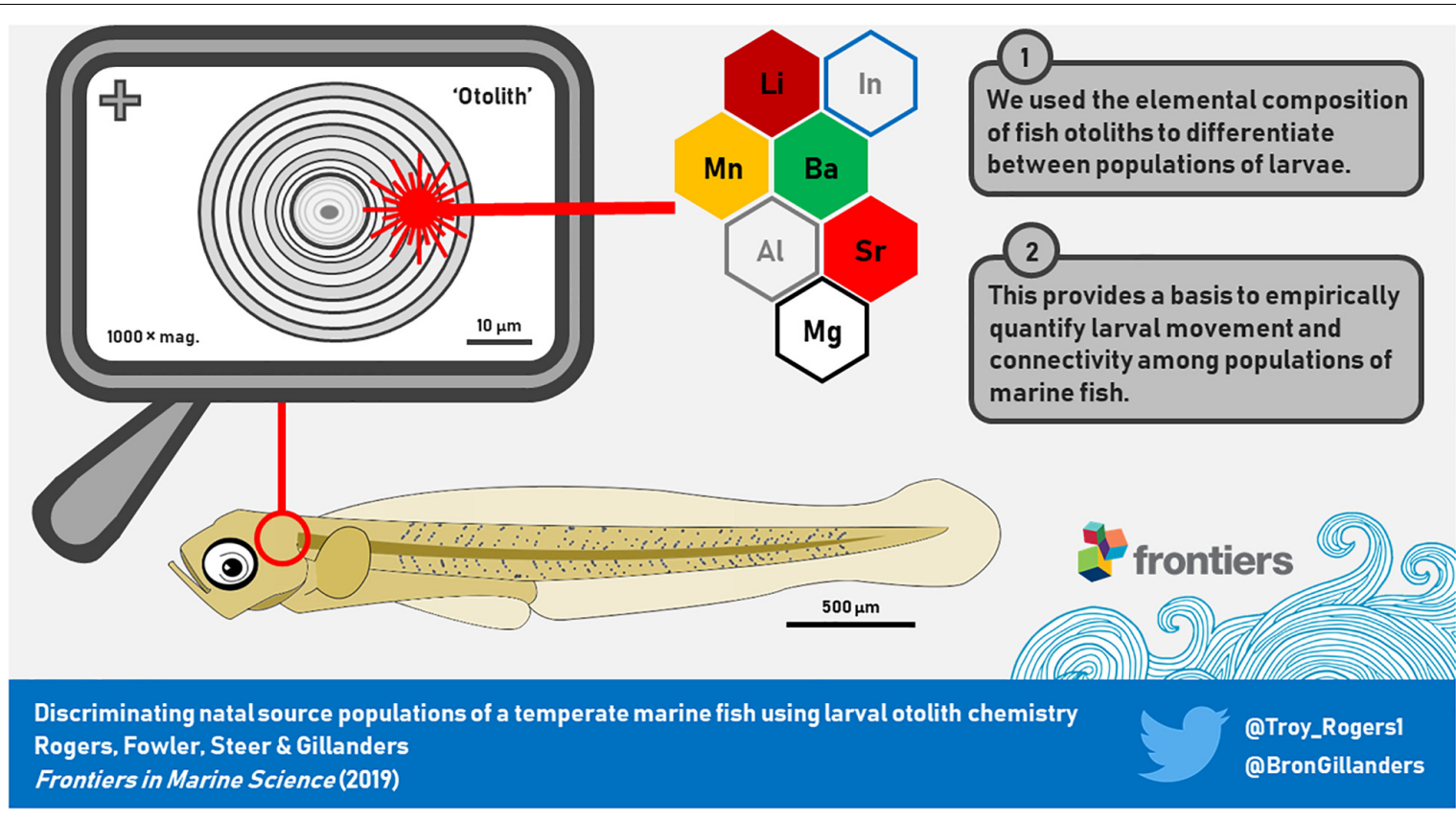

GRAPHICAL ABSTRACT | The elemental composition of microscopic otoliths of fish larvae were used as an environmental marker to differentiate between populations of larvae. The ability to discriminate between larvae that originated from different source populations provides a basis to quantify larval movement in marine ecosystems.

that originate from different source populations (Norcross and Shaw, 1984; Cowen and Sponaugle, 2009; Leis et al., 2011). Identifying the degree of larval exchange among populations is necessary to understand population dynamics and inform stock structure. However, quantifying larval movement among populations remains a significant challenge. On one hand, a population may be primarily maintained by larval production and dispersal from other populations, and is considered demographically open (Caley et al., 1996). Alternatively, larvae may recruit to the population to which they were born and the population is demographically closed as it is essentially selfrecruiting (Swearer et al., 1999; Jones et al., 2005). It is likely that most marine populations are maintained by a combination of both processes - i.e., a proportion of self-recruitment that is supplemented by larval production from other populations (Swearer et al., 2002; Cowen and Sponaugle, 2009).

The most significant barrier to empirically quantifying larval movement has been the difficulty in differentiating between larvae from different source populations (Thorrold et al., 2002; Cowen and Sponaugle, 2009). This is largely associated with the logistical challenges involved in marking inherently small larvae that experience extremely high mortality rates. In recent years, natural environmental markers, such as the geochemical signatures in calcified structures, have become a leading approach to study the biology of even the smallest aquatic animals (Campana, 1999; Thorrold et al., 2007; Tzadik et al., 2017). The otoliths (ear stones) of teleost fishes are paired crystalline structures that form during embryonic development and record environmental information at a highly resolved temporal scale (Campana, 1999; Elsdon et al., 2008). They form increments at a daily periodicity which can be used to estimate age, and in turn, calculate hatch dates and larval growth rates (Campana and Neilson, 1985; Campana and Jones, 1992). The calcium carbonate generated during daily increment formation is derived from the surrounding aquatic environment, which contains elements in minor and trace quantities that can be incorporated into the otolith at the precipitating surface. Once incorporated, these elements are permanently retained and represent a chronological record of environmental history (Campana, 1999; Elsdon et al., 2008). The geochemical signatures in otoliths can be used as a tool to discriminate between fish populations, and have been successfully applied to assess stock structure (Campana et al., 1994; Tanner et al., 2016), reconstruct ontogenetic movement patterns (Elsdon and Gillanders, 2003; Fowler et al., 2005), and evaluate the contributions of source populations to nursery areas (Gillanders and Kingsford, 1996; Tanner et al., 2012).

The analysis of otolith chemistry has the potential to discriminate between source populations of larvae by comparing the elemental signatures of their otoliths prior to dispersal (Thorrold et al., 2002; Barbee and Swearer, 2007). Most studies of larval otolith chemistry have considered the otoliths of embryonic larvae from substrate-attached egg masses before the larvae have hatched (e.g., Warner et al., 2005; Ruttenberg and Warner, 2006; Barbee and Swearer, 2007; Standish et al., 2008). In such cases, the entire otolith relates to embryonic development at the single location where the eggs were collected. However, most commercially important marine fish species are broadcast spawners that produce large numbers of pelagic eggs and larvae (Sadovy, 2001; Murua and Saborido-Rey, 2003). Relatively few studies have considered pelagic larvae 
(but see Ludsin et al., 2006; Lazartigues et al., 2014, 2017), and even fewer have considered pelagic larvae in marine environments (but see Brophy et al., 2003; Schaffler et al., 2009). This likely relates to a number of factors that include: the logistical challenges involved in collecting recently hatched larvae from open marine ecosystems; the limited amount of calcified material deposited at the natal origin because of the potential for dispersal immediately after spawning; and the analytical difficulties in detecting differences in elemental signatures where environmental gradients are potentially less pronounced (Barbee and Swearer, 2007; Standish et al., 2008).

King George whiting (Sillaginodes punctatus; Perciformes) is a demersal marine finfish species that is endemic to temperate coastal waters of southern Australia, where it supports important commercial and recreational fisheries (Kailola et al., 1993; Steer et al., 2018). South Australia is at the center of this geographic distribution and provides the highest State-based catches (Mobsby, 2018). However, in recent years, catches from two of the most productive fishery regions, Spencer Gulf and Gulf St. Vincent, have declined to record lows. In addition, there are differences in regional population characteristics that may be indicative of localized population processes (Steer et al., 2018). Despite extensive research of the life history of this species (Fowler and Short, 1996; Jenkins et al., 1997; Fowler et al., 1999, 2000a; Jenkins et al., 2000, 2016), there remains considerable uncertainty about the source populations that replenish nursery areas in different regions. Across south-eastern Australia, the only recognized spawning area for King George whiting is in southern Spencer Gulf and Investigator Strait, which is the region that connects the two gulf systems (Figure 1; Fowler et al., 1999, 2000b). Adults are multiple batch spawners that release pelagic eggs repeatedly between March and June (Fowler et al., 1999). The larvae undergo a prolonged dispersal phase of 3-5 months during the austral winter, from which the survivors eventually settle in protected bays between July and November (Fowler and Short, 1996; Jenkins et al., 1997; Fowler et al., 2000a; Rogers et al., 2019a). However, in South Australia, the relationships between the recognized spawning ground and nursery areas are poorly understood.

A recent study identified significant differences in the natal otolith chemistry of larvae that settled to nursery areas in Spencer Gulf and Gulf St. Vincent, suggesting that recruits in each gulf originated from different source populations (Rogers et al., 2019b). Because of the short distances between the nursery areas in these regions and the recognized spawning area, there are two primary hypotheses regarding the sources of larvae to nursery areas in Spencer Gulf and Gulf St. Vincent. The first hypothesis is that the recognized spawning area is comprised of multiple different source populations that replenish nursery areas in each region. Alternatively, larvae that recruit to one region may originate from the recognized spawning area, whilst the larvae that recruit to the other region may originate from a different spawning source elsewhere. The aim of this study was to determine if larval King George whiting in their natal waters of southern Spencer Gulf and Investigator Strait originated from a common source population. The specific objectives were to: (1) identify the distribution and abundance of recently hatched

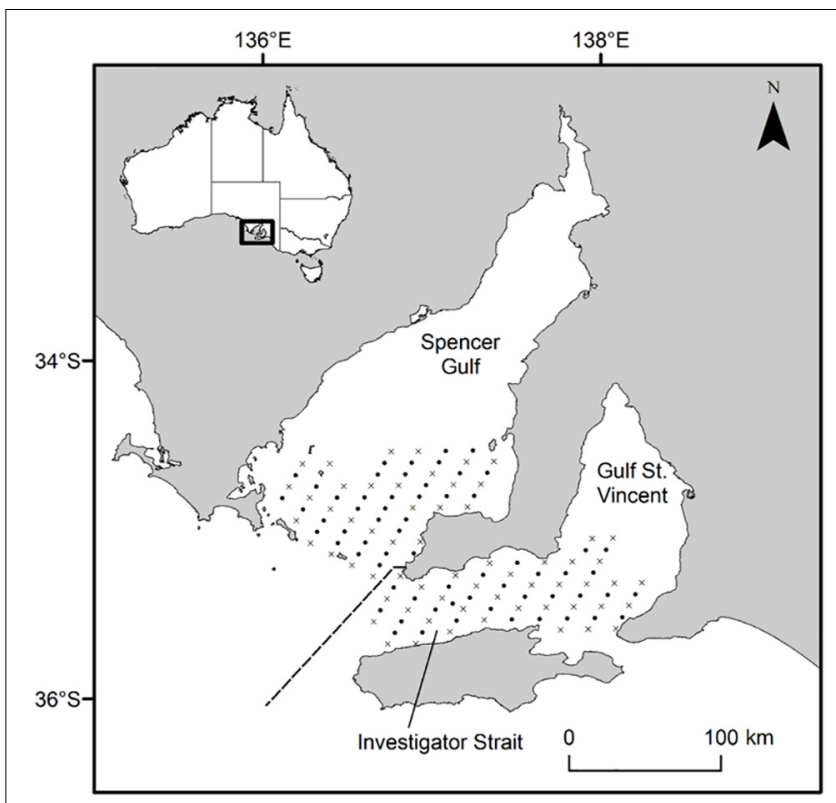

FIGURE 1 | Map of South Australia's gulf systems showing the

geo-referenced stations where plankton samples were collected in 2017 and 2018. Oblique tows $(\bullet)$ were done at every station $(n=126)$ and vertical tows with CTD casts $(x)$ at almost every second station $(n=62)$. The dashed line separates Southern Spencer Gulf and Investigator Strait stations. Inset, map of Australia showing the study area along the southern coastline.

larvae throughout Southern Spencer Gulf and Investigator Strait; and (2) compare the early life history characteristics and otolith chemistry of larvae to assess the potential for different source populations. Otolith chemistry signatures could then be compared between larvae and recruits to evaluate hypotheses concerning population connectivity and stock structure.

\section{MATERIALS AND METHODS}

\section{Study Area}

This study focused on recently hatched King George whiting larvae in the recognized spawning area throughout southern Spencer Gulf and Investigator Strait, South Australia (Figure 1; Fowler et al., 1999, 2000b). This area connects the semienclosed seas of Spencer Gulf and Gulf St. Vincent, to the oceanic waters of the eastern Great Australian Bight. The region experiences significant seasonal changes in physical environmental characteristics and oceanographic regimes which largely relate to the formation of frontal systems at the mouths of Spencer Gulf and Investigator Strait (Petrusevics, 1993; Middleton and Bye, 2007; Petrusevics et al., 2011). Temperature and salinity increase in the gulfs during the austral summer, which leads to the formation of thermohaline fronts that inhibit shelf-gulf exchange. The frontal systems dissipate as gulf temperatures decrease in late autumn (May), and shelf/gulf exchange resumes as lower density shelf water is drawn into southern Spencer Gulf and Investigator Strait. 


\section{Sample Collection}

Larvae were sampled on two research cruises from April 25 to May 1, 2017 and April 24-30, 2018 aboard the RV Ngerin at 126 geo-referenced stations arranged in a $4 \times 2 \mathrm{~nm}$ grid pattern (Figure 1). Plankton samples were collected from a combination of oblique and vertical tows using paired bongo nets of $0.57 \mathrm{~m}$ diameter with $500 \mu \mathrm{m}$ mesh. An oblique tow was done at every station $(n=126)$, whilst a vertical tow was done at almost every second station $(n=62)$. Each net was fitted with a flow-meter which was calibrated using factory coefficients to estimate the distance traveled by each net during each tow (General Oceanics, 2030; FL, United States). Plankton samples were preserved in $100 \%$ ethanol and refrigerated at $4^{\circ} \mathrm{C}$ prior to sorting. A SBE 19plus V2 SeaCAT Profiler CTD (SeaBird Scientific, WA, United States) was attached to the bottom of the vertical net frame and recorded temperature $\left({ }^{\circ} \mathrm{C}\right)$ and salinity at $1 \mathrm{~m}$ intervals during each vertical net tow. King George whiting eggs are buoyant and the larvae remain near the surface until post-flexion (Bruce, 1995; Ham and Hutchinson, 2003). Therefore, we considered the mean CTD data from the surface to $5 \mathrm{~m}$ depth to best represent the environmental conditions experienced during early ontogeny. Maps were created in ArcGIS (v. 10.6; ESRI, CA, United States).

\section{Sample Processing}

Larval fish were sorted from the plankton using a modified Sedgwick-Rafter sorting tray under a dissecting microscope (Olympus SZX7; Tokyo, Japan). Larval King George whiting were identified following the morphological descriptions by Bruce (1995). The primary diagnostic characteristics were: shallowbodied, elongate larvae with a small head; a single series of dorsal and ventral melanophores; and a moderate to long uncoiled gut (Figure 2A; Bruce, 1995). To aid identification, larvae were viewed at $20 \times$ magnification on a computer screen using an Olympus DP73 video camera attached to the microscope, and used Olympus Stream software (v. 1.9.1; Tokyo, Japan). Morphological identifications were verified using an in situ hybridization (ISH) molecular technique. This technique uses a horseradish peroxidase (HRP) enzyme conjugated oligonucleotide probe that binds specifically to mitochondrial $16 \mathrm{~S}$ ribosomal RNA of King George whiting and generates a blue color through oxidization with a HRP reactive substrate (Figure 3; Oxley et al., 2017). The ISH probe was applied to a tissue sample from each larva after the head had been removed to prevent potential contamination of the otoliths. The identification of all King George whiting larvae used in otolith analyses $(n=134)$ was verified using the ISH molecular technique (Table 1).

At each station, the density of larvae per volume of water filtered was estimated by the equation:

$$
D=\frac{n}{V}
$$

where $D$ is the density of larvae (ind. per $\mathrm{m}^{3}$ ), $n$ is the number of larvae in each sample, and $V$ is the volume of water filtered $\left(\mathrm{m}^{3}\right) . V$ was calculated as the area of the paired nets $\left(2 \times \pi r^{2}\right)$ multiplied by the distance traveled according to the flowmeter

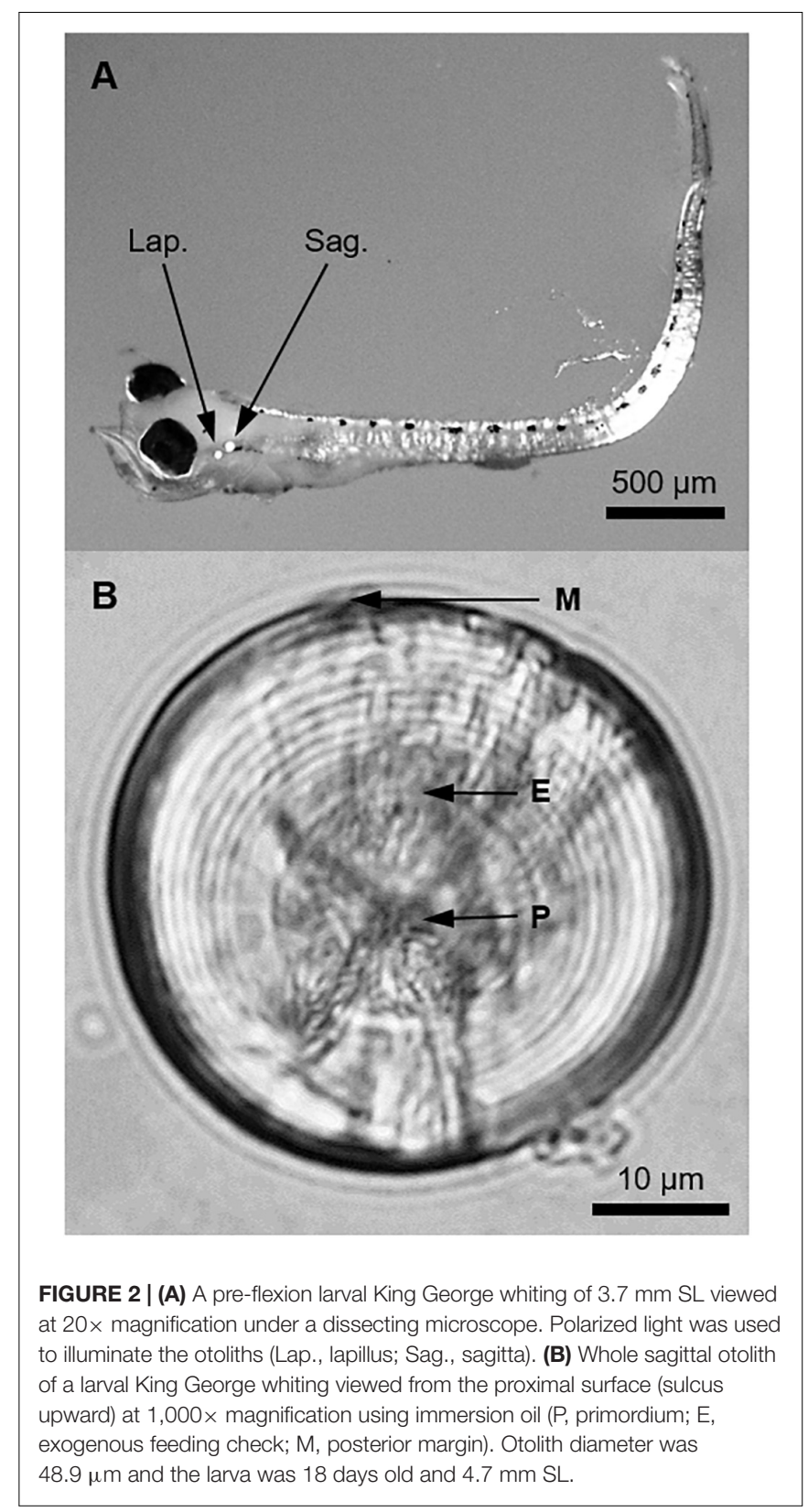

readings. Each larva was measured for standard length (SL) to the nearest $0.1 \mathrm{~mm}$. Larvae ranged in size from 1.6 to $9.3 \mathrm{~mm}$ SL. However, we constrained otolith analyses to larvae of $\leq 5 \mathrm{~mm}$ to minimize potential dispersion from their natal environment. In 2018, the abundance of larvae in Investigator Strait was considerably higher than elsewhere, and therefore a random sub-sample of larvae $(n=42)$ representative of the overall distribution was used for otolith analyses. The otoliths (sagittae and lapilli) were clearly visible in the heads of the larvae under a dissecting microscope at $60 \times$ magnification fitted with a polarizing filter (Figure 2A). Only the sagittal otoliths were used for analyses, which were extracted using stainless steel dissecting needles. Hereafter, a fine-tipped synthetic paintbrush was used for all otolith transfers to prevent contamination from metallic 

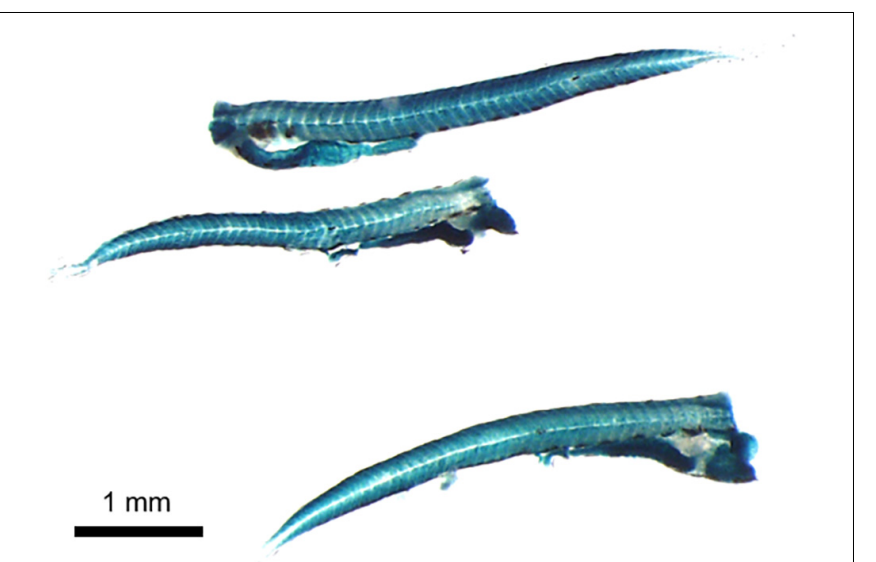

FIGURE 3 | Larval King George whiting following confirmation of identification using the in situ hybridization (ISH) molecular technique. Larvae were viewed at $20 \times$ magnification under a dissecting microscope. The head of each larva was removed to prevent potential contamination of the otoliths.

instruments. Otoliths were rinsed in a drop of ultrapure water, then transferred to a bath of ultrapure $15 \% \mathrm{H}_{2} \mathrm{O}_{2}$ buffered with $0.1 \mathrm{~N} \mathrm{NaOH}$ for $15 \mathrm{~min}$ to remove adhering organic material (Warner et al., 2005; Barbee and Swearer, 2007; Standish et al., 2011). Otoliths were then transferred through three drops of ultrapure water to remove residual cleaning solution and were then air dried under a laminar flow hood.

\section{Otolith Microstructure}

The sagittae from King George whiting larvae are hemispherical in shape, with a convex proximal surface (sulcus face) and almost flat distal surface. One otolith from each larva $(n=134)$ was randomly selected for microstructure analysis, and the other was used for trace element chemistry. The former was viewed whole, orientated sulcus face upward in immersion oil, at 1,000× magnification under a compound microscope (Olympus BX51; Tokyo, Japan). For interpretation, each otolith was viewed on a computer screen using an image analysis system (Olympus DP73 video camera, Olympus Stream v. 1.9.1; Tokyo, Japan). Otoliths were measured from the anterior to posterior margins to the nearest $0.1 \mu \mathrm{m}$. Daily increment formation for otoliths of King George whiting has been validated from reared larvae of known age (B. D. Bruce and D. A. Short, unpublished). Increments were counted from the primordium to the posterior margin (Figure 2B). Two counts were done for each otolith. If these counts differed, additional counts were done until an acceptable estimate of age was achieved. If not, the otolith was rejected $(n=3)$. After aging, each otolith was cleaned of oil and mounted in thermoplastic glue (CrystalBond 509; ProSciTech, QLD, Australia) for storage.

Larval growth rates were calculated in two ways. The "average growth rate" $\left(\mathrm{mm} \mathrm{d}^{-1}\right)$ provided an estimate of mean daily growth rate from hatch to capture, and was calculated as:

$$
\frac{L_{c}-L_{o}}{a}
$$

where $L_{c}$ is length at capture, $L_{o}$ is length at hatch $(2.1 \mathrm{~mm}$; Bruce, 1995), and $a$ is age $(d)$. However, this method provides no information on daily variation in growth rate. As such, retrospective length at age and daily growth rates were calculated from otolith increment widths using the "back-calculation with biological intercept algorithm" (Campana, 1990; Campana and Jones, 1992). This technique depends on proportional somatic and otolith growth, for which there were strong linear relationships in each year $\left(r^{2}=0.79\right.$ and 0.78 in 2017 and 2018, respectively; Supplementary Figure S1). Daily increments were measured from the primordium to posterior margin to the nearest $0.1 \mu \mathrm{m}$, and the size of each larva on successive days was estimated by the equation:

$$
L_{a}=L_{c}+\left(\frac{\left(O_{a}-O_{c}\right)\left(L_{c}-L_{o}\right)}{\left(O_{c}-O_{o}\right)}\right)
$$

where $L_{a}$ is the length at age $a, L_{c}$ is length at capture, $L_{o}$ is length at hatch (2.1 mm; Bruce, 1995), $O_{a}$ is the otolith radius at age $a, O_{c}$ is the otolith radius at capture, and $O_{o}$ is otolith radius at hatch. Here, $O_{o}$ was defined as the distance from the closest increment to the primordium, and $O_{a}$ was calculated from accumulating successive increments (Fowler and Short, 1996). The estimates of size at age and daily growth rate were averaged across larvae in each region and year.

\section{Trace Element Chemistry}

Otolith chemistry preparation and analytical processing were modified from Barbee and Swearer (2007). A gridded microscope slide was coated with a thin layer of thermoplastic glue (CrystalBond 509; ProSciTech, QLD, Australia), which was spiked with indium $\left({ }^{115} \mathrm{In}\right)$ at $\sim 200 \mathrm{ppm}$ to aid discrimination during analysis (Reis-Santos et al., 2012). On each slide, up to 20 otoliths were orientated sulcus face upward on individual grid squares on top of the hardened thermoplastic glue. The slide was then heated on a hotplate for $3 \mathrm{~s}$ at $80^{\circ} \mathrm{C}$ to soften the glue, which

TABLE 1 | Summary of sample details used to compare otolith microstructure and elemental chemistry of larval King George whiting from Southern Spencer Gulf and

\begin{tabular}{|c|c|c|c|c|c|c|c|c|c|}
\hline Year & Region & $n$ & Stations & $\begin{array}{l}\text { Fish length } \\
(\mathrm{mm})\end{array}$ & $\begin{array}{l}\text { Otolith diameter } \\
\qquad(\mu \mathrm{m})\end{array}$ & $\begin{array}{l}\text { Age } \\
(d)\end{array}$ & $\begin{array}{l}\text { Ave. growth rate } \\
\left(\mathrm{mm} \mathrm{d}^{-1}\right)\end{array}$ & $\begin{array}{l}\text { Temperature } \\
\left({ }^{\circ} \mathbf{C}\right)\end{array}$ & $\begin{array}{c}\text { Salinity } \\
\text { (ppt) }\end{array}$ \\
\hline \multirow[t]{2}{*}{2017} & Spencer Gulf & 19 & 13 & $4.0(0.6)$ & $40.6(8.7)$ & $13.3(3.0)$ & $0.140(0.03)$ & $19.2(0.7)$ & $37.0(0.6)$ \\
\hline & Investigator Strait & 31 & 11 & $3.9(0.6)$ & $41.3(9.1)$ & $13.7(3.5)$ & $0.136(0.03)$ & $18.6(0.2)$ & $36.2(0.1)$ \\
\hline \multirow[t]{2}{*}{2018} & Spencer Gulf & 39 & 19 & $3.9(0.4)$ & 41.9 (7.9) & $13.1(2.6)$ & $0.137(0.02)$ & $19.5(0.5)$ & $36.7(0.6)$ \\
\hline & Investigator Strait & 42 & 17 & $3.8(0.4)$ & $37.4(7.0)$ & $11.8(2.6)$ & $0.140(0.02)$ & $19.2(0.5)$ & $36.4(0.2)$ \\
\hline
\end{tabular}
Investigator Strait in 2017 and 2018.

$n$, number of larvae; stations, no. of stations larvae sourced from. All other values are in the form mean (SD). 
caused the otoliths to "sink" into it using their own mass. This meant that each otolith was mounted in glue around its margin, but presented a largely exposed proximal surface for laser ablation (Figure 4A). A total of seven such slides were prepared and stored in resealable plastic bags prior to analysis.

Otoliths were analyzed for trace element chemistry by laser ablation-inductively coupled plasma-mass spectrometry (LAICP-MS). The system consisted of a Resonetics ASI (ACT, Australia) $193 \mathrm{~nm}$ excimer LA system coupled to an Agilent (Santa Clara, CA, United States) 7900 quadrupole ICP-MS, which was located at Adelaide Microscopy (Adelaide, SA, Australia). Up to four slides, each bearing 20 otoliths, were placed in the sealed chamber at one time and viewed remotely using a video camera. Otoliths were ablated using a $19 \mu \mathrm{m}$ diameter laser "spot" at a pulse rate of $4 \mathrm{~Hz}$ and a beam density at the sample of $\sim 3.5 \mathrm{~J} \mathrm{~cm}^{-2}$. Each otolith was sampled through the primordium from the proximal to distal surfaces. Due to the small diameter of larval otoliths $(21.2-61.7 \mu \mathrm{m})$, no pre-ablation pass was done. Instead, the first $2 \mathrm{~s}$ of data were cropped to remove data that could have been affected by possible surface contamination. Ablation occurred in a ${ }^{4} \mathrm{He}$ flushed chamber that was mixed with ${ }^{40} \mathrm{Ar}$ for injection into the plasma. The elements quantified for analysis were ${ }^{7} \mathrm{Li},{ }^{25} \mathrm{Mg},{ }^{55} \mathrm{Mn},{ }^{88} \mathrm{Sr}$, and ${ }^{138} \mathrm{Ba}$, as well as ${ }^{43} \mathrm{Ca}$ that was used as the internal standard. The concentration of otolith ${ }^{43} \mathrm{Ca}$ was assumed to be constant at $38.8 \%$ (Yoshinaga et al., 2000). ${ }^{115} \mathrm{In}$ was also measured to aid discrimination between otolith material and thermoplastic glue during analysis (Reis-Santos et al., 2012), and ${ }^{27} \mathrm{Al}$ was measured as an indicator of metallic contamination (Lazartigues et al., 2016). Calibration was achieved against the National Institute of Standards (NIST) 612 glass standard (Lahaye et al., 1997). Background measurements were recorded for $30 \mathrm{~s}$ prior to each sample ablation, with a measurement of each element recorded every $0.17 \mathrm{~s}$. Sample acquisition times ranged from $\sim 15$ to $35 \mathrm{~s}$ due to the different sizes of otoliths. Data reduction, including background subtractions and calculation of minimum detection limits (MDL), was done offline in the Igor Pro workspace using Iolite software (v. 2.5; Paton et al., 2011). Data were converted to molar concentrations and standardized

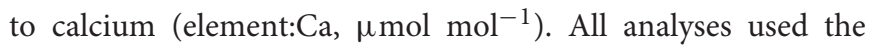
element:Ca data.

Internal precision and accuracy were assessed by analyzing the NIST 612 as an unknown sample against the known concentrations, and external precision was assessed by measurements of MACS-3 (United States Geological Survey; VA, United States) calcium carbonate reference material. NIST 612 and MACS-3 were analyzed twice at the beginning and end of each session, and after every 10 ablations to correct for instrumental drift $(n=18)$. Mean recovery for the NIST 612 was $99.99-100.05 \%$ for each element. Mean relative standard deviation (RSD) for NIST 612 was: $0.6 \%(\mathrm{Li}), 1.1 \%(\mathrm{Mg}), 0.3 \%$ $(\mathrm{Mn}), 0.3 \%(\mathrm{Sr})$, and $0.5 \%(\mathrm{Ba})$. External precision (RSD) assessed by measurements of MACS-3 was: 3.3\% (Li), 3.9\% (Mg), $2.0 \%(\mathrm{Mn}), 3.7 \%(\mathrm{Sr})$ and $2.7 \%(\mathrm{Ba})$. Mean MDL $\left(\mu \mathrm{mol} \mathrm{mol}{ }^{-1}\right)$ based on three times the standard deviation of the blank gases adjusted for ablation yield (Lahaye et al., 1997) were: $0.39(\mathrm{Li})$, $1.63(\mathrm{Mg}), 0.56(\mathrm{Mn}), 0.02(\mathrm{Sr})$, and $0.02(\mathrm{Ba})$.

\section{Data Analysis}

\section{Environmental and Biological Characteristics}

Environmental (temperature and salinity) and biological (length, age, otolith diameter and average growth rate) characteristics were compared between regions and years by two-way analysis of variance (ANOVA). Region and year were fixed factors in the full factorial model. Parametric assumptions of normality (Shapiro-Wilk) and equality of group variances (Levene's Test) were satisfied after square-root transformation. When significant differences were found, Tukey HSD post hoc comparisons were used to determine the source of differences between group means. Individual growth trajectories calculated from daily increment widths were compared between regions and years by repeated-measures analysis of variance (RM-ANOVA). Statistical analyses were done using SPSS Statistics (v. 26.0; IBM Corp., NY, United States).

\section{Trace Element Chemistry}

The concentration of $\mathrm{Mn}$ was used to separate the elemental data in two parts (Barbee and Swearer, 2007). Mn concentrations spiked at the primordium, which were consistent with larval otolith chemistry studies of other species (e.g., Brophy et al., 2004; Barbee and Swearer, 2007; Macdonald et al., 2008; Lazartigues et al., 2017). The two areas were: (1) “primordial area"- mean elemental concentrations of the 25 scans surrounding the peak count in Mn (Figure 4B). This incorporated the primordium and the immediately surrounding otolith material, and relates to the earliest stages of embryonic development and larval growth. It is representative of the "natal origin" of pelagic larvae ( 0 to $\sim 5$ days post fertilization). (2) "Non-primordial area"mean elemental concentrations from the proximal surface to the primordial area. This corresponds to larval development from the onset of exogenous feeding until the time of capture $(\sim 5$ to 20 days).

The elemental ratios of $\mathrm{Li}: \mathrm{Ca}, \mathrm{Mg}: \mathrm{Ca}, \mathrm{Mn}: \mathrm{Ca}, \mathrm{Sr}: \mathrm{Ca}$, and Ba:Ca exceeded the detection limits of the ICP-MS for all samples (100\%). Parametric assumptions were violated for Li:Ca regardless of transformation type. Therefore, to apply a consistent statistical approach to all elements and enable them to be combined for multivariate analyses, non-parametric tests were used. For each area of the otolith, elemental chemistry was compared between regions and years using a two-factor PERMANOVA design for each element individually and all elements combined (Anderson, 2001). Region and year were fixed factors in the full factorial model. Element:Ca data were normalized prior to constructing resemblance matrices based on Euclidean distance dissimilarity, and analyzed using unrestricted permutation with 9999 random repeats. When significant differences were found, post hoc pair-wise comparisons were used to identify the source of differences between means. Multivariate data were reduced to two-dimensions and visualized using non-metric multidimensional scaling (nMDS) and canonical analysis of principal coordinates (CAP) (Anderson and Willis, 2003). Multi-elemental data were compared between spatial groups of larvae in each year, and then pooled together in a single analysis to evaluate variation between years. Vector diagrams in each canonical plot show the influence of individual 


\section{A}

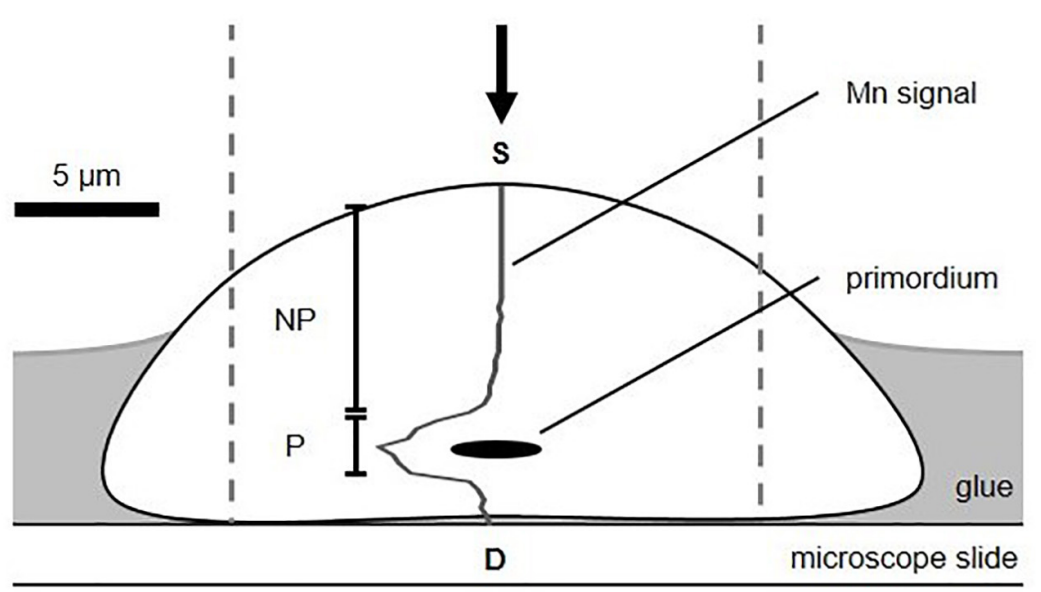

B

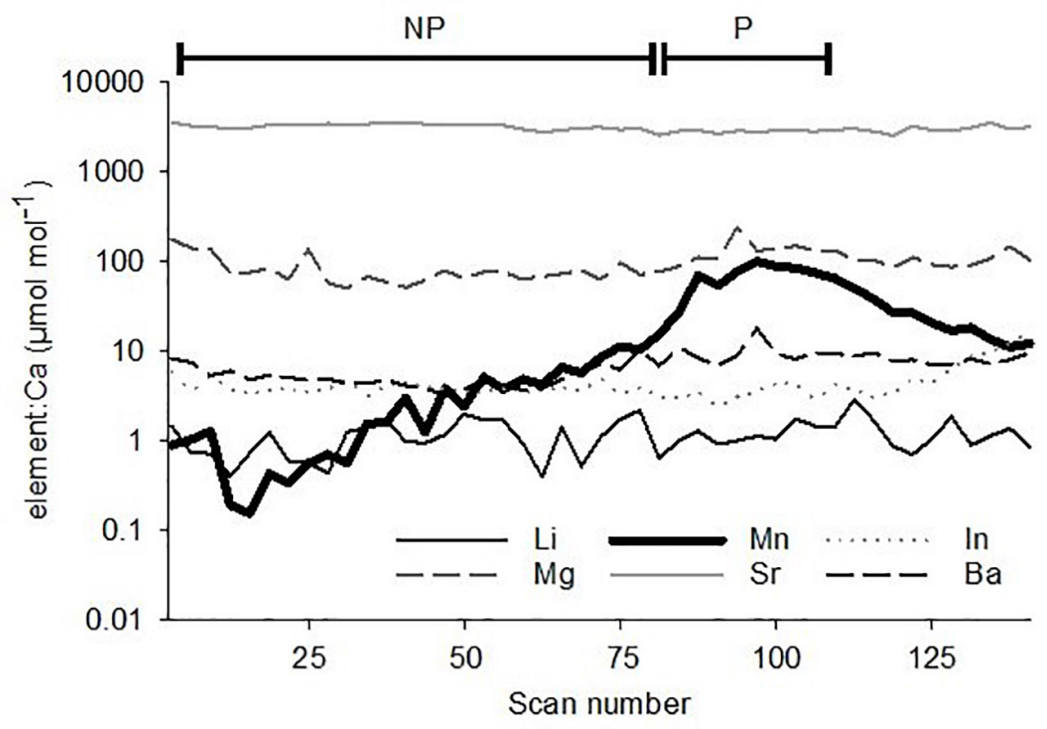

FIGURE 4 | (A) Schematic cross-section of a sagittal otolith from a larval King George whiting mounted sulcus face upward on a microscope slide in preparation for elemental analysis. Dashed lines show the area that the LA-ICP-MS ablation path encompassed. The arrow indicates the direction of laser ablation. ${ }^{55} \mathrm{Mn}$ signal is overlaid on the otolith. (B) Example of a time-resolved multi-elemental profile for a larval otolith ablated through the primordium from the proximal (S) to distal (D) surfaces. Note the logarithmic scale. NP, non-primordial area; P, primordial area.

elements to sample positioning in multivariate space. The relative length and direction of each vector correspond to its discriminatory ability. Leave-one-out cross validation was used to classify larvae to groups for each region and year based on the multi-elemental signals of the remaining samples. The performance of CAP to discriminate between groups was evaluated using Cohen's Kappa $(\kappa)$ statistic, which is a method of calculating the chance-corrected percentage of agreement between actual and predicted group memberships. Values of $\kappa$ range from 0 to 1 , where 0 indicates that the CAP resulted in no improvement over chance, and 1 indicates perfect agreement (Titus et al., 1984). Statistical analyses were done using PRIMER (v. 7.0.13; Auckland, NZ) and figures were produced using SigmaPlot (v. 14.0; Systat Software Inc., San Jose, CA, United States).

\section{RESULTS}

\section{Environmental Characteristics}

In both 2017 and 2018, there were strong temperature and salinity gradients that increased northward in southern Spencer Gulf and eastward in Investigator Strait (Figure 5). In 2017, temperature ranged from 17.8 to $19.9^{\circ} \mathrm{C}$ in southern Spencer Gulf and 17.9 to $19.6^{\circ} \mathrm{C}$ in Investigator Strait. Despite withinregion variation, southern Spencer Gulf was significantly warmer than Investigator Strait (Supplementary Figure S2). Water temperatures across the study area were $0.5-0.7^{\circ} \mathrm{C}$ warmer in 2018. Salinity also showed greater variation within than between regions. The largest variation in salinity was in southern Spencer Gulf in 2017 which increased from 35.6 to 37.5. In 2017, salinity was significantly higher in southern Spencer 


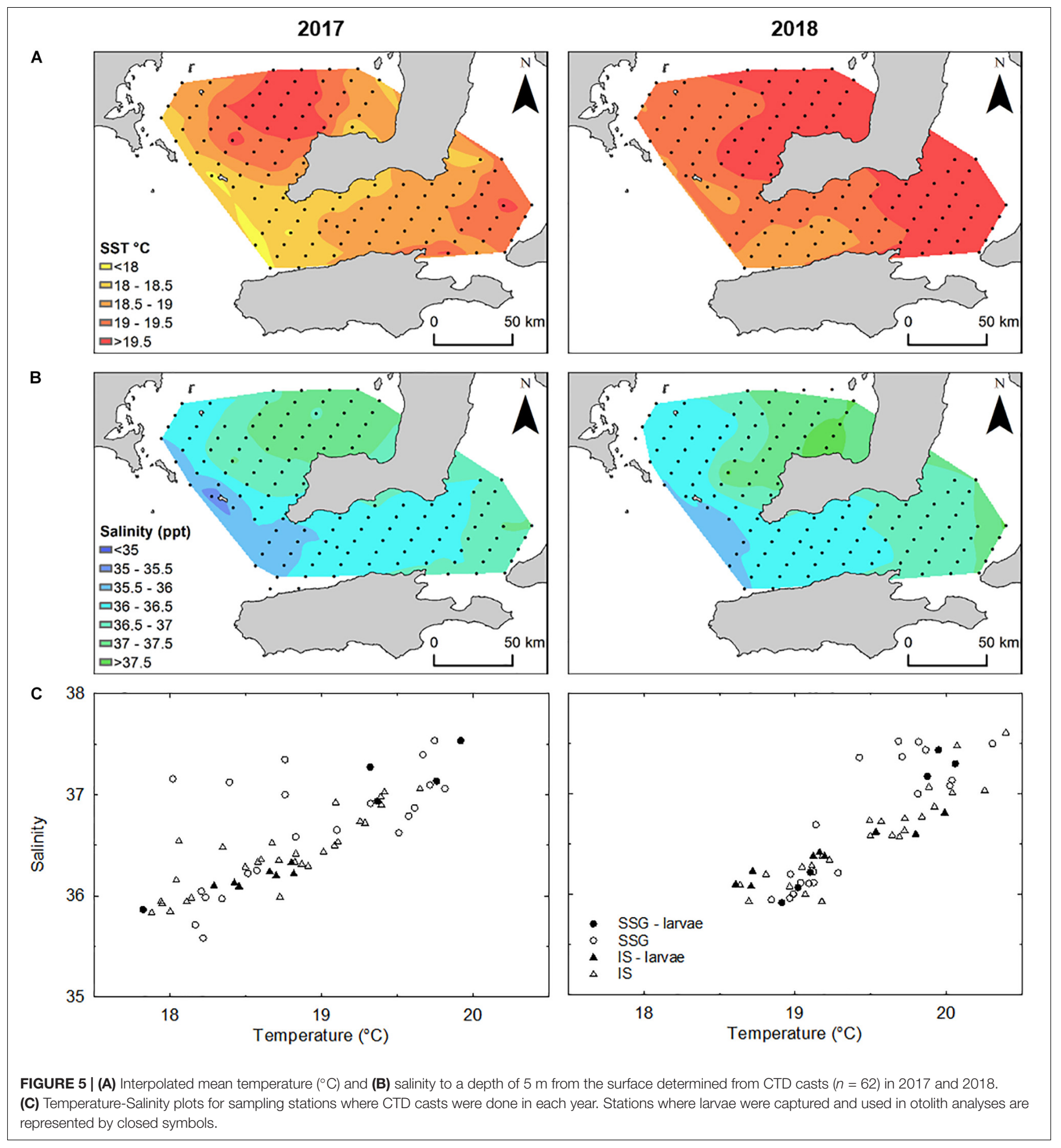

Gulf than Investigator Strait, but there were no differences in 2018 or between years. Although there were no regional differences for temperature and salinity in 2018, T-S plots separated the sampling stations into two clusters in each region (Figure 5C): (1) low temperature $\left(18.6-19.3^{\circ} \mathrm{C}\right)$ and low salinity (35.8-36.5); and (2) high temperature $\left(19.5-20.5^{\circ} \mathrm{C}\right)$ and high salinity (36.5-37.5).

\section{Larval Distribution}

In total, 360 larval King George whiting were captured throughout the study $(n=100$ in 2017 and $n=260$ in 2018). Larvae ranged in size from 1.6 to $7.6 \mathrm{~mm} \mathrm{SL}$ in 2017, and 1.7 to $9.3 \mathrm{~mm} \mathrm{SL}$ in 2018. The spatial distribution of larvae was similar in both years. Larvae in Investigator Strait were distributed as a single group at a high density, 
whereas larvae in southern Spencer Gulf were distributed in small patches at lower densities (Figure 6A). In both years, larval abundance and density was higher in Investigator Strait than southern Spencer Gulf. There was a break in the distribution of larvae between the two regions. Based on the spatial distribution, larvae were separated into two groups: (1) southern Spencer Gulf and (2) Investigator Strait. The larvae considered for otolith analyses from these two groups were $\leq 5.0 \mathrm{~mm}$ SL to ensure that there had been minimal dispersion from the place where they had been spawned. The distribution of larvae of this size range was consistent with the overall distribution of larvae of mixed sizes (Figure 6B). The highest density of larvae $\leq 5.0 \mathrm{~mm}$ SL was in Investigator Strait in both years.

\section{Early Life History Characteristics}

The larvae used for otolith analyses ranged in size from 3.0 to $5.0 \mathrm{~mm} \mathrm{SL}$ and in age from 5 to 21 days (Figure 7). There were no differences in the sizes and ages of larvae between regions or years (Supplementary Table S1). Otolith diameter for these larvae ranged from 21.2 to $61.7 \mu \mathrm{m}$ and were strongly related to standard length and age $\left(r^{2}=0.75\right.$ and $r^{2}=0.78$, respectively). Otoliths of larvae $\leq 3.0 \mathrm{~mm}$ SL were not large enough $(\leq 20 \mu \mathrm{m}$ diameter) for elemental analysis with LA-ICP-MS. In 2017 larvae hatched from April 8 to April 24, and in 2018 from April 7 to April 23. Mean hatch dates did not differ between regions or years. There was considerable variation in average growth rates which ranged from 0.09 to $0.21 \mathrm{~mm} \mathrm{~d}^{-1}$. However, there were no differences between regions or years. Furthermore, there were no differences in average growth rates between larvae from the low and high temperature groups in 2018 ( $t$-test; $t=0.44$, $\mathrm{df}=24, P=0.667)$. Mean daily growth rates calculated from increment measurements showed a significant ontogenetic shift, although there were no differences between regions or years (Supplementary Table S2). The range was from 0.17 to $0.20 \mathrm{~mm}$ $\mathrm{d}^{-1}$ for age $0-4$ days, then declined considerably on day 5 from 0.11 to $0.13 \mathrm{~mm} \mathrm{~d}^{-1}$ and then remained consistent from age 5 to 15 days (Figure 8).

\section{Trace Element Chemistry Individual Elements}

There was considerable variation in the elemental concentrations in otoliths that resulted in numerous spatial and temporal differences (Figure 9 and Table 2). For the primordial area, concentrations of $\mathrm{Li}$ and $\mathrm{Ba}$ differed between regions in 2017, being considerably higher for Investigator Strait than southern

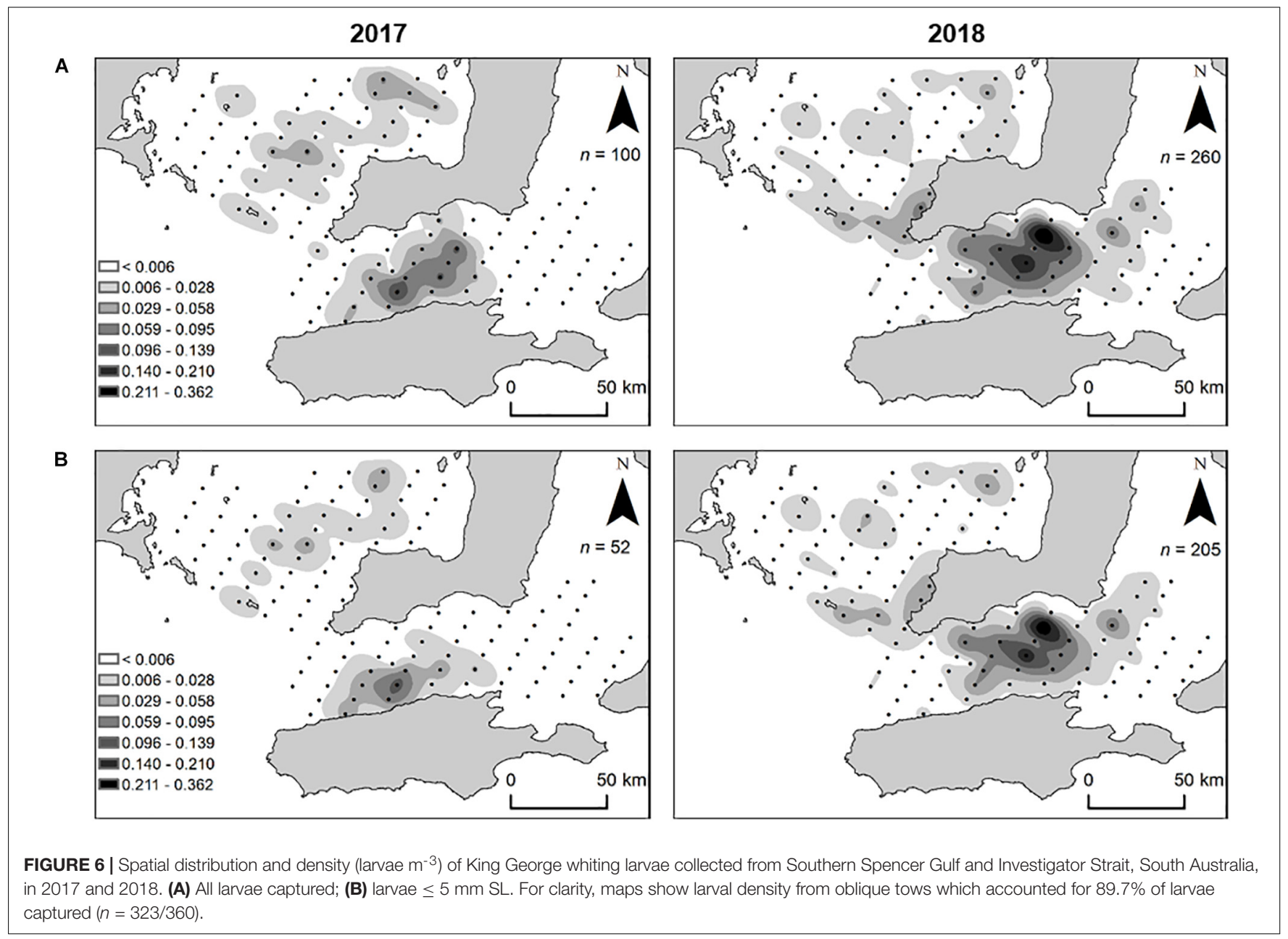



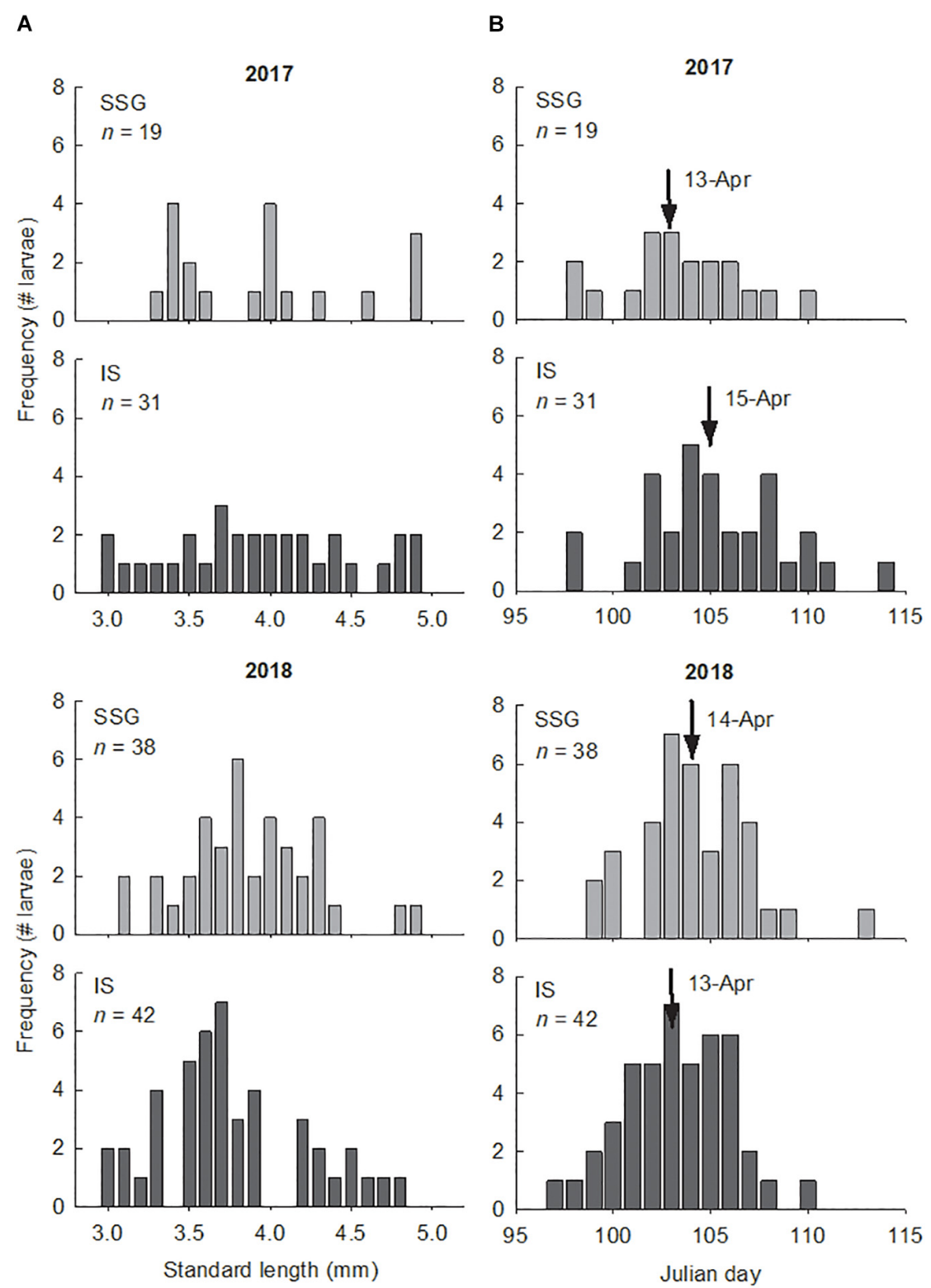

FIGURE 7 | (A) Length frequency distributions of King George whiting larvae from Southern Spencer Gulf (SSG) and Investigator Strait (IS) in 2017 and 2018. Size was constrained to larvae of $\leq 5 \mathrm{~mm}$ SL. (B) Frequency histograms showing the number of aged larvae that hatched on the nominated Julian day in 2017 and 2018 Arrows identify the mean hatch day.

Spencer Gulf (Figure 9A). Li concentrations were fourfold higher for Investigator Strait in 2017, but in 2018, there were no differences. Instead, regional differences were observed for $\mathrm{Mg}$ and $\mathrm{Ba}$ which were both higher for Investigator Strait. Ba was consistently higher for Investigator Strait than southern Spencer Gulf in each year. The concentrations of each element differed significantly between years. Concentrations of $\mathrm{Li}, \mathrm{Mn}$ and $\mathrm{Ba}$ were higher in 2017, whilst Mg and Sr were higher in 2018. Concentrations of $\mathrm{Mn}$ were 10-20-fold higher for the primordial area compared to the remainder of the otolith.

For the non-primordial area, Li was the only element that differed between regions (Table 2). Concentrations of Li were higher for Investigator Strait than southern Spencer Gulf in each year, with the magnitude of difference considerably greater in 2017 (Figure 9B). There were significant between-year differences for the concentrations of $\mathrm{Li}, \mathrm{Mg}$, and $\mathrm{Ba}$, which were consistent with the primordial area of the otolith. Concentrations of Sr were higher in Investigator Strait in 2017, but higher in southern Spencer Gulf in 2018.

\section{Multi-Elemental Signatures}

When individual elements were combined into a single matrix, significant differences were evident between regions in each year for the primordial area (Table 2). Regional differences were 


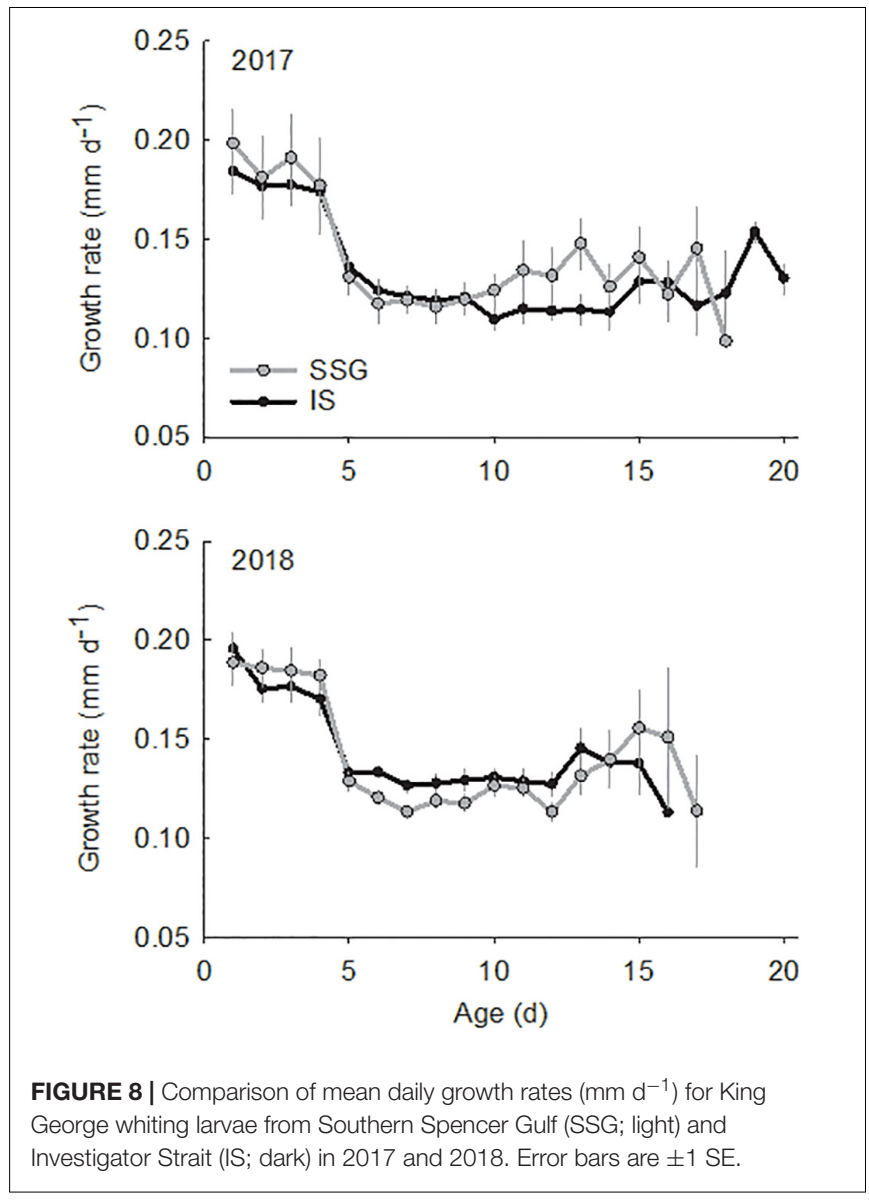

considerably greater in 2017 due to higher concentrations of $\mathrm{Li}$ for Investigator Strait. Regional differences in 2017 were driven by $\mathrm{Li}$ and $\mathrm{Ba}$, and in 2018 by $\mathrm{Ba}$ (Figure 10A). Interannual differences in $\mathrm{Li}, \mathrm{Mn}$, and $\mathrm{Sr}$ were responsible for significant differences in regional multi-elemental signatures between years. Overall classification of larvae back to their region of capture was 82 and $70 \%$ in 2017 and 2018, respectively, and ranged from 66 to $94 \%$ for individual regions (Table 3 ).

For the non-primordial area, multi-elemental signatures differed between regions in 2017 but not 2018. Regional differences in 2017 were exclusively driven by higher concentrations of $\mathrm{Li}$ for Investigator Strait. Inter-annual variation in concentrations of $\mathrm{Li}, \mathrm{Mg}$, and $\mathrm{Sr}$ were responsible for differences in regional multi-elemental signatures between years (Figure 10B). Overall classification success was $80 \%$ in 2017, but was considerably lower in 2018 at 53\% (Table 3). When both regions and years were combined in a single analysis, elemental signatures were most similar among regions within the same year (Supplementary Table S3).

\section{DISCUSSION}

The aim of this study was to determine whether larval King George whiting in their natal waters of southern Spencer

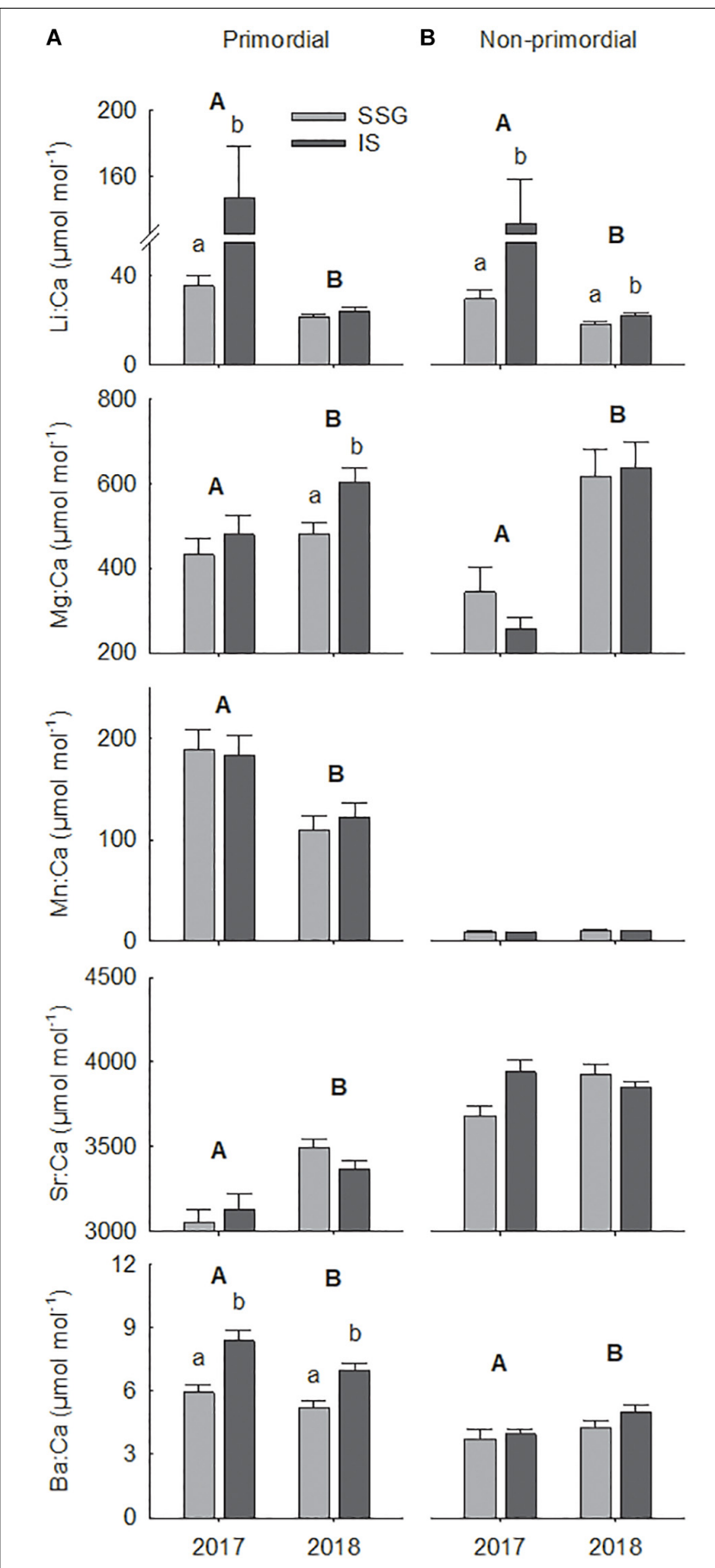

FIGURE 9 | Regional comparisons of mean element:Ca ratios $\left(\mu \mathrm{mol} \mathrm{mol}{ }^{-1}\right.$ ) for the (A) primordial area and (B) non-primordial area of larval King George whiting otoliths in 2017 and 2018. Letters identify significant differences $(P<0.05$; capitals, between years; lower case, between regions). Error bars are +1 SE. SSG, Southern Spencer Gulf (light); IS, Investigator Strait (dark).

Gulf and Investigator Strait originated from a common source population. Firstly, we described the distribution and abundance of larvae throughout the only recognized spawning area in southern Australia. We then used the incremental structure and 
TABLE 2 | Summary of two-factor PERMANOVAs for the effect of year and region on individual and combined element: Ca ratios for the (a) primordial area and (b) non-primordial area of larval King George whiting otoliths.

\begin{tabular}{|c|c|c|c|c|c|c|c|c|c|c|c|c|c|}
\hline & \multirow[b]{2}{*}{ df } & \multicolumn{2}{|c|}{ Li } & \multicolumn{2}{|c|}{$\mathrm{Mg}$} & \multicolumn{2}{|c|}{ Mn } & \multicolumn{2}{|c|}{$\mathrm{Sr}$} & \multicolumn{2}{|c|}{$\mathrm{Ba}$} & \multicolumn{2}{|c|}{ All elements } \\
\hline & & MS & $\boldsymbol{F}$ & MS & $\boldsymbol{F}$ & MS & $\boldsymbol{F}$ & MS & $\boldsymbol{F}$ & MS & $\boldsymbol{F}$ & MS & $\boldsymbol{F}$ \\
\hline \multicolumn{14}{|l|}{ (a) Primordial } \\
\hline Year & 1 & 22.35 & $35.08^{* * *}$ & 6.70 & $7.32^{* *}$ & 12.48 & $13.65^{* * *}$ & 23.05 & $28.45^{* * *}$ & 5.76 & $7.43^{* *}$ & 70.34 & $17.36^{* * *}$ \\
\hline Region & 1 & 10.87 & $17.06^{* * *}$ & 3.64 & $3.97^{*}$ & 0.01 & 0.01 & 0.15 & 0.19 & 19.88 & $25.65^{* * *}$ & 34.55 & $8.53^{* * *}$ \\
\hline Year × Region & 1 & 8.14 & $12.78^{* * *}$ & 0.99 & 1.08 & 0.36 & 0.40 & 1.61 & 1.99 & 0.08 & 0.11 & 11.18 & $2.76^{*}$ \\
\hline Residuals & 127 & 0.64 & & 0.92 & & 0.91 & & 0.81 & & 0.78 & & 4.05 & \\
\hline \multicolumn{14}{|c|}{ (b) Non-primordial } \\
\hline Year & 1 & 22.20 & $35.52^{* * *}$ & 30.48 & $41.48^{* * *}$ & $<0.01$ & $<0.01$ & 2.39 & 2.56 & 4.66 & $4.85^{*}$ & 59.73 & $13.95^{* * *}$ \\
\hline Region & 1 & 13.03 & $20.85^{* * *}$ & 0.23 & 0.32 & $<0.01$ & $<0.01$ & 2.62 & 2.79 & 2.87 & 2.99 & 18.76 & $4.38^{* *}$ \\
\hline Year × Region & 1 & 7.57 & $12.11^{* *}$ & 0.47 & 0.64 & $<0.01$ & $<0.01$ & 8.25 & $8.81^{* *}$ & 0.01 & 0.01 & 16.31 & $3.81^{* *}$ \\
\hline Residuals & 127 & 0.62 & & 0.73 & & 1.03 & & 0.94 & & 0.96 & & 4.28 & \\
\hline
\end{tabular}

Year and region were fixed factors. ${ }^{*} P<0.05 ;{ }^{*} P<0.01 ;{ }^{* * *} P<0.001$.

multi-elemental signatures recorded in their otoliths to assess the potential for different source populations within the large spawning area.

\section{Environmental Characteristics}

The incremental structure and elemental composition of calcified structures is heavily influenced by the aquatic environment, and as such, geographic differences in environmental characteristics underpin the use of otolith-based techniques to discriminate between fish populations (Campana, 1999; Elsdon et al., 2008).

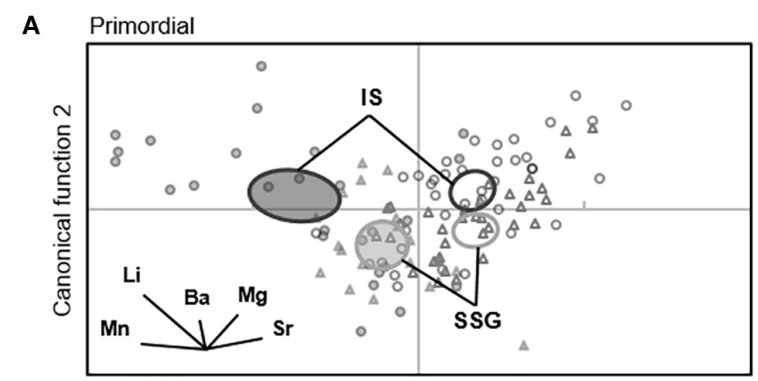

B

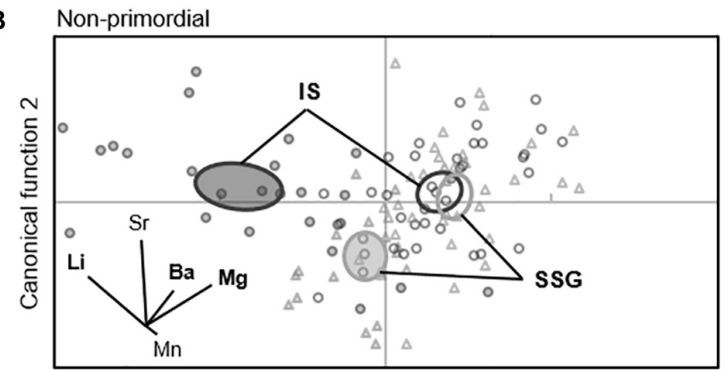

FIGURE 10 | Canonical variate plots of the multi-elemental chemistry for the (A) primordial area and (B) non-primordial area of larval King George whiting otoliths in 2017 (shaded) and 2018 (open). Ellipses show 95\% confidence around group means. Vector diagrams show the direction and weight of individual elements to sample distribution. Elements in bold contribute most to group differences. SSG, Southern Spencer Gulf ( $\mathbf{\Lambda}$, light); IS, Investigator Strait $(\bullet$, dark).
Physical and chemical gradients in open marine environments are generally less pronounced compared to estuarine and freshwater systems (Standish et al., 2008). Even so, only small changes in environmental characteristics may be sufficient to be manifested as detectable differences in otolith elemental concentrations. For example, Atlantic croaker larvae collected from three water masses in the Mid-Atlantic Bight based on temperature and salinity showed significantly different otolith chemistry, suggesting that multiple source populations contributed to recruitment (Schaffler et al., 2009). In the present study, significant differences in temperature and salinity were evident between southern Spencer Gulf and Investigator Strait in 2017 that corresponded to distinct otolith

TABLE 3 | Classification success for the spatial comparison of multi-elemental chemistry for the (a) primordial and (b) non-primordial areas of larval King George whiting otoliths in 2017 and 2018.

\begin{tabular}{lccc}
\hline & & SSG & IS \\
\hline (a) Primordial & & & \\
2017 & SSG & $\mathbf{9 4}$ & 6 \\
& IS & 26 & $\mathbf{7 4}$ \\
& Overall & $\mathbf{8 2}$ & \\
& $\kappa$ & 0.65 & 34 \\
& SSG & $\mathbf{6 6}$ & $\mathbf{7 4}$ \\
& IS & 26 & \\
& Overall & $\mathbf{7 0}$ & \\
(b) Non-primordial & $\kappa$ & 0.39 & 11 \\
2017 & & & $\mathbf{7 4}$ \\
& SSG & $\mathbf{8 9}$ & \\
& IS & 26 & \\
& Overall & $\mathbf{8 0}$ & 40 \\
2018 & $\kappa$ & 0.60 & $\mathbf{4 7}$ \\
& SSG & $\mathbf{6 0}$ & \\
& IS & 53 & \\
& Overall & $\mathbf{5 3}$ & \\
& $\kappa$ & 0.07 &
\end{tabular}

Data represent the percentage (\%) of larvae from the region of capture (row) allocated to each region (column). Bold values are correctly assigned. SSG, Southern Spencer Gulf; IS, Investigator Strait. 
signatures for larvae in each region. In 2018, environmental differences between regions were less prominent, which was reflected in greater similarity among regional otolith signatures. However, unlike Schaffler et al. (2009), we were unable to confidently discriminate between water masses based solely on environmental characteristics. Temperature and salinity demonstrated a similar gradient within each region in both years that increased away from the mouth into the two gulfs. These environmental gradients are characteristic of the seasonal thermohaline frontal systems that form at the entrance of Spencer Gulf and Investigator Strait (Bruce and Short, 1990; Petrusevics, 1993; Petrusevics et al., 2011).

\section{Distribution and Abundance of Larvae}

The spatial distribution and density of larvae differed considerably between southern Spencer Gulf and Investigator Strait. Larval abundance and density was higher for Investigator Strait in both 2017 and 2018, with larvae concentrated in the middle of the strait. In contrast, larvae in southern Spencer Gulf were distributed as a mosaic of small patches of low densities. For the latter region, in 2018, the highest densities of larvae were collected at the frontal zone across the mouth of the gulf. The patterns of larval distribution and areas of highest abundance in this study were consistent with those observed throughout the same study area in 1999 (Fowler, 2000). There was a discontinuity in the distribution of larvae between the two regions that corresponded to the environmental gradients at the entrances to Spencer Gulf and Investigator Strait. These observations provide further support to the findings of previous studies which have suggested that the frontal systems act as environmental barriers which inhibit water exchange, and subsequent plankton transport, during the austral summer and autumn (Bruce and Short, 1990; Petrusevics, 1993; Fowler, 2000; Petrusevics et al., 2011). Because the seasonality of the frontal systems coincides with the peak spawning period for King George whiting (Fowler et al., 1999, 2000b), it is possible that eggs and larvae in Spencer Gulf and Investigator Strait are separated until exchange between the gulfs and the waters of the continental shelf resumes after the fronts have dissipated.

\section{Early Life History Characteristics}

Otolith microstructure analysis is a useful tool for investigating the early life history characteristics of developing larvae, which can be used to discriminate between fish that have occupied different environments (Campana and Neilson, 1985; Campana and Jones, 1992; Watai et al., 2018). The discriminatory power of this technique largely depends on variation in somatic growth rates that manifest as differences in otolith increment widths. However, despite spatial differences in temperature, we found no differences in the sizes, ages, hatch dates or average growth rates of larvae between regions or years. Furthermore, there were no spatial differences in daily growth trajectories from the otolith increment widths. The only difference evident was an ontogenetic shift in the daily growth rates of all larvae at 5 days post hatch, that would be associated with the transition from endogenous to exogenous feeding (Bruce, 1995). Because of the similar environmental gradients in each region, it is possible that spatial differences were masked when samples were combined into regional groups. However, that appears unlikely because of the weak relationships between early life history (e.g., average growth rate) and environmental characteristics (e.g., temperature). Another possibility is that the spatial variation in temperature $\left(\sim 2^{\circ} \mathrm{C}\right)$ and salinity $(\sim 2 \mathrm{ppt})$ may have been insufficient to affect somatic growth, and therefore was not manifested in the otolith structure. Regardless, we were unable to discriminate between groups of larvae based on the characteristics derived from otolith microstructure analysis.

The primary interest of the analyses of otolith chemistry was to compare the multi-elemental signatures of larvae to determine if they had originated from a common source population. We identified significant differences in otolith chemistry between larvae from southern Spencer Gulf and Investigator Strait in each year, although the magnitude of difference was considerably greater in 2017. The differences suggest larvae from the two regions were hatched into, and subsequently developed in, water masses with different physical and/or chemical conditions that influenced otolith chemistry (Campana, 1999; Elsdon et al., 2008). There was considerable inter-annual variation in regional multi-elemental signatures, with the magnitude of difference between years greater than regional differences within years. Such inter-annual variation has implications for characterizing the geochemical signatures of larval populations, and also for studies that consider the natal signatures of otoliths from juvenile or adult fish (Gillanders, 2002; Reis-Santos et al., 2012).

In addition to differences among regions and years, there was considerable variation in elemental concentrations within otoliths. Spatial and temporal variation was considerably higher in the primordial area compared to the non-primordial area. The largest difference was a significant increase in $\mathrm{Mn}$ concentration at the primordium. Such elevated concentrations are unlikely to reflect environmental availability, but rather relate to physiological processes during embryonic development or crystallization of the otolith nucleus (Brophy et al., 2004; Ruttenberg et al., 2005). Barbee and Swearer (2007) separated larval otolith chemistry data in the same way, but found equally strong differences among populations for the primordial and non-primordial areas. The early life history of their species of interest involves substrate-attached egg masses, and therefore all the otolith material related to embryonic development at a single location. In contrast, the pelagic eggs and larvae of broadcast spawning species are subject to dispersal immediately after being released (Norcross and Shaw, 1984; Cowen and Sponaugle, 2009). The potential for transport is even greater for marine species that reproduce in exposed coastal or open waters. Because larvae of such species may only remain near their spawning ground for a short period of time, such as a few days, the amount of otolith material that corresponds to the natal environment is likely to be very limited (Barbee and Swearer, 2007; Standish et al., 2008). As such, for pelagic marine larvae the elemental composition of the otolith material that immediately surrounds the primordium may best reflect the natal environment. However, recent research suggests that otolith formation during embryonic development is considerably influenced by maternally derived chemical signatures, which could potentially mask environmentally driven variation (Hegg et al., 2018; Loeppky et al., 2018). Consequently, it is necessary 
to separate the elemental data accordingly to account for such maternal effects.

\section{Ecological Interpretation of Elemental Signatures}

Larvae from southern Spencer Gulf and Investigator Strait hatched at the same time and developed at a similar rate, but had significantly different multi-elemental signatures relating to their natal origin. The differences in otolith chemistry indicate that larvae in the two regions occupied spatially segregated water masses, and suggest that each region supports its own spawning population (Campana, 1999; Elsdon et al., 2008). Evidence of two distinct spawning populations within the recognized spawning area has considerable implications for understanding the ontogenetic connectivity and stock structure of King George whiting. Spatial differences in multi-elemental signatures were primarily driven by concentrations of $\mathrm{Ba}$ and Li. Specifically, in both years, the otoliths of larvae from Investigator Strait showed significantly higher Ba concentrations compared to those from Spencer Gulf. Otolith Ba incorporation in marine fishes generally reflects ambient availability and shows a negative relationship with salinity (Elsdon and Gillanders, 2005; Walther and Thorrold, 2006; Izzo et al., 2018). A similar trend in otolith $\mathrm{Ba}$ concentration was identified for the natal signatures of settled King George whiting recruits, with those in Gulf St. Vincent having considerably higher $\mathrm{Ba}$ concentrations than Spencer Gulf (Rogers et al., 2019b). As such, the most parsimonious hypothesis is that each putative source population replenishes nursery areas in the adjacent gulf region, and as such, each gulf supports a largely closed population. That is, for Spencer Gulf, larvae are spawned in the south and disperse northward to the nursery areas, whilst larvae spawned in Investigator Strait disperse eastward and replenish nursery areas in Gulf St. Vincent. This scenario is consistent with the meta-population structure of King George whiting in South Australia hypothesized by Fowler et al. (2000a) and Rogers et al. (2019b). Because the two spawning grounds are separated by $50-100 \mathrm{~km}$, only small-scale adult movement is required for exchange between populations to maintain genetic homogeneity (Kent et al., 2018).

Otolith Li concentrations for 10 of 25 larvae collected from Investigator Strait in 2017 were drastically higher than for larvae from elsewhere in either year. The mean Li concentration in the otoliths of these larvae was $287.4 \mu \mathrm{mol} \mathrm{mol}{ }^{-1}$ (compared to $32.9 \mu \mathrm{mol} \mathrm{mol}{ }^{-1}$ for the other larvae in the sample), which exceeded any published otolith Li concentrations $(<50 \mu \mathrm{mol}$ $\mathrm{mol}^{-1}$ ). These larvae were collected at three consecutive sampling stations within $2 \mathrm{~h}$ of each other, and all larvae from these stations demonstrated exceedingly high $\mathrm{Li}$ values. We believe that sample contamination is unlikely because larvae were randomized at each stage of processing, were processed in a clean laboratory, and there were no systematic differences in the concentrations of the other elements measured from the same otoliths. One possible explanation is that the pronounced Li concentrations reflect a localized environmental phenomena that was directly manifested in otolith chemistry (Elsdon et al., 2008; Izzo et al., 2018). Lithium is only present in the salt fraction of endolymphatic fluid and is therefore unlikely to directly substitute for calcium at the precipitating surface (Thomas et al., 2017). As such, incorporation of Li into the otolith most likely occurs through random trapping in interstitial spaces of aragonite crystal during daily increment formation, and may reflect ambient concentrations (Izzo et al., 2016; Thomas et al., 2017). Lithium incorporation could also be facilitated by increased interstitial space following the substitution of calcium for elements with larger atomic radii, such as $\mathrm{Sr}$ or Ba (de Vries et al., 2005). However, there were no systematic changes in these elements with Li concentrations. Another possibility is that the elevated Li signature may have been maternally transferred, and in which case, the larvae were the progeny of a common spawning female (Thorrold et al., 2006; Starrs et al., 2013). Regardless of the source of Li, spatio-temporal differences in otolith chemistry remained similar when $\mathrm{Li}$ was excluded from multi-elemental analyses (see Supplementary Appendix A).

\section{Implications and Future Directions}

A common application of otolith chemistry is to analyze the natal signatures of juvenile or adult fish to estimate the number of source populations that contribute to recruitment (e.g., Gillanders and Kingsford, 1996; Standish et al., 2011; Tanner et al., 2012). Whilst such studies provide considerable insight into population connectivity and stock structure, they cannot identify the source populations from where larvae originated and the degree to which populations rely on larval production from elsewhere. This was the situation with King George whiting in South Australia. There was evidence to suggest that recruits in Spencer Gulf and Gulf St. Vincent originated from different source populations (Rogers et al., 2019b). In the present study, we determined that the recognized spawning area throughout southern Spencer Gulf and Investigator Strait constitutes two source populations based on the elemental composition of larval otoliths. The next step is to explore the relationships between the different spawning grounds and nursery areas to understand population dynamics and inform stock structure. One possible approach is to simulate larval dispersal using a biophysical model (Fowler et al., 2000a; Jenkins et al., 2000). This technique has been successfully applied to simulate larval transport of western king prawns in Spencer Gulf (McLeay et al., 2016), and has the capacity to be applied to King George whiting. Alternatively, otolith chemistry has the potential to empirically quantify larval movement between populations. This can be achieved by collecting larvae from all potential source populations, characterizing the elemental signatures of their otoliths, and then comparing them to the natal signatures of juveniles in different nursery areas. In this way, otolith chemistry can be used to address ecological questions not currently approachable using other techniques.

\section{DATA AVAILABILITY STATEMENT}

The datasets generated for this study are available on request to the corresponding author. 


\section{ETHICS STATEMENT}

Sample collection and processing was reviewed and approved by The University of Adelaide Animal Ethics Committee (S2016-133).

\section{AUTHOR CONTRIBUTIONS}

TR, AF, MS, and BG conceived and designed the study. TR, $\mathrm{AF}$, and MS assisted with sample collection. TR wrote the manuscript, performed the laboratory processing and sample preparation, operated the LA-ICP-MS, collected and analyzed the data, and applied the statistical analyses. AF, MS, and BG revised the manuscript.

\section{FUNDING}

Operating costs were largely funded by the Fisheries Research and Development Corporation (Project No. 2016-003). Larval otolith chemistry analysis (LA-ICP-MS) was funded by a Holsworth Wildlife Research Endowment Grant (Ecological Society of Australia), awarded to TR. This study was part of a Ph.D. by TR who was supported by an Australian

\section{REFERENCES}

Anderson, M. J. (2001). A new method for non-parametric multivariate analysis of variance. Aust. Ecol. 26, 32-46. doi: 10.1111/j.1442-9993.2001.010 70.pp.x

Anderson, M. J., and Willis, T. J. (2003). Canonical analysis of principal coordinates: a useful method of constrained ordination for ecology. Ecology 84, 511-525. doi: 10.1890/0012-9658(2003)084\%5B0511:caopca\%5D2. $0 . \mathrm{co} ; 2$

Barbee, N. C., and Swearer, S. E. (2007). Characterizing natal source population signatures in the diadromous fish Galaxias maculatus, using embryonic otolith chemistry. Mar. Ecol. Prog. Ser. 343, 273-282. doi: 10.3354/meps0 6886

Brophy, D., Danilowicz, B., and Jeffries, T. (2003). The detection of elements in larval otoliths from Atlantic herring using laser ablation ICP-MS. J. Fish Biol. 63, 990-1007. doi: 10.1046/j.1095-8649.2003.00223.x

Brophy, D., Jeffries, T. E., and Danilowicz, B. S. (2004). Elevated manganese concentrations at the cores of clupeid otoliths: possible environmental, physiological, or structural origins. Mar. Biol. 144, 779-786. doi: 10.1007/ s00227-003-1240-3

Bruce, B. D. (1995). Larval development of King George whiting, Sillaginodes punctata, school whiting, Sillago bassensis, and yellow fin whiting, Sillago schomburgkii (Percoidei: Sillaginidae), from South Australian waters. Fish. Bull. 93, 27-43.

Bruce, B. D., and Short, D. A. (1990). Observations on the distribution of larval fish in relation to a frontal zone at the mouth of Spencer Gulf, South Australia. Bureau Rural Resour. Proc. 15, 124-137.

Caley, M., Carr, M., Hixon, M., Hughes, T., Jones, G., and Menge, B. (1996). Recruitment and the local dynamics of open marine populations. Annu. Rev. Ecol. Syst. 27, 477-500. doi: 10.1146/annurev.ecolsys.27.1.477

Campana, S. E. (1990). How reliable are growth back-calculations based on otoliths? Can. J. Fish. Aquat. Sci. 47, 2219-2227. doi: 10.1139/f90-246

Campana, S. E. (1999). Chemistry and composition of fish otoliths: pathways, mechanisms and applications. Mar. Ecol. Prog. Ser. 188, 263-297. doi: 10.3354/ meps 188263
Post-graduate Award (APA) and a Playford Memorial Trust Ph.D. Scholarship.

\section{ACKNOWLEDGMENTS}

We thank M. Drew, A. Hogg, D. Matthews, P. Rogers, and the crew of the RV Ngerin for assisting with sample collection. M. Drew and E. Westlake sorted mixed larvae from plankton samples. We thank S. Swearer (University of Melbourne, Australia) for discussions about larval otolith chemistry and providing an otolith processing protocol. S. Gilbert (Adelaide Microscopy, Australia) assisted with LA-ICP-MS operation. A. Oxley (SARDI) developed and applied the ISH technique to verify larval identifications. D. Matthews prepared the maps. Additional logistic support was provided by the South Australian Research and Development Institute (Aquatic Sciences). We thank the reviewers for comments that greatly improved the manuscript.

\section{SUPPLEMENTARY MATERIAL}

The Supplementary Material for this article can be found online at: https://www.frontiersin.org/articles/10.3389/fmars. 2019.00711/full\#supplementary-material

Campana, S. E., Fowler, A. J., and Jones, C. M. (1994). Otolith elemental fingerprinting for stock identification of Atlantic cod (Gadus morhua) using laser ablation ICPMS. Can. J. Fish. Aquat. Sci. 51, 1942-1950. doi: 10.1139/f9 4-196

Campana, S. E., and Jones, C. M. (1992). "Analysis of otolith microstructure data," in Otolith Microstructure Examination and Analysis, Book 117. Canadian Special Publication of Fisheries and Aquatic Sciences, eds D. K. Stevenson, and S. E. Campana, (Ottowa: Department of Fisheries and Oceans).

Campana, S. E., and Neilson, J. D. (1985). Microstructure of fish otoliths. Can. J. Fish. Aquat. Sci. 42, 1014-1032. doi: 10.1139/f85-127

Cowen, R. K., Lwiza, K. M., Sponaugle, S., Paris, C. B., and Olson, D. B. (2000). Connectivity of marine populations: open or closed? Science 287, 857-859. doi: $10.1126 /$ science.287.5454.857

Cowen, R. K., and Sponaugle, S. (2009). Larval dispersal and marine population connectivity. Annu. Rev. Mar. Sci. 1, 443-466. doi: 10.1146/annurev.marine. 010908.163757

de Vries, M. C., Gillanders, B. M., and Elsdon, T. S. (2005). Facilitation of barium uptake into fish otoliths: influence of strontium concentration and salinity. Geochim. Cosmochim. Acta 69, 4061-4072. doi: 10.1371/journal.pone.0218446

Elsdon, T., and Gillanders, B. (2005). Consistency of patterns between laboratory experiments and field collected fish in otolith chemistry: an example and applications for salinity reconstructions. Mar. Freshw. Res. 56, 609-617.

Elsdon, T. S., and Gillanders, B. M. (2003). Reconstructing migratory patterns of fish based on environmental influences on otolith chemistry. Rev. Fish Biol. Fish. 13, 217-235. doi: 10.1023/b:rfbf.0000033071.73952.40

Elsdon, T. S., Wells, B. K., Campana, S. E., Gillanders, B. M., Jones, C. M., Limburg, K. E., et al. (2008). Otolith chemistry to describe movements and life-history parameters of fishes: hypotheses, assumptions, limitations and inferences. Oceanogr. Mar. Biol. Annu. Rev. 46, 297-330.

Fowler, A. J. (2000). Preliminary Assessment of the Application of the Daily egg Production Method for Estimating the Spawning Biomass of King George Whiting (Sillaginodes punctata) in South Australian Waters. Adelaide, SA: South Australian Research and Development Institute.

Fowler, A. J., Black, K. P., and Jenkins, G. P. (2000a). Determination of spawning areas and larval advection pathways for King George whiting in southeastern 
Australia using otolith microstructure and hydrodynamic modelling. II. South Australia. Mar. Ecol. Prog. Ser. 199, 243-254. doi: 10.3354/meps199243

Fowler, A. J., Gillanders, B., and Hall, K. (2005). Relationship between elemental concentration and age from otoliths of adult snapper (Pagrus auratus, Sparidae): implications for movement and stock structure. Mar. Freshw. Res. 56, 661-676.

Fowler, A. J., McLeay, L., and Short, D. (1999). Reproductive mode and spawning information based on gonad analysis for the King George whiting (Percoidei: Sillaginidae) from South Australia. Mar. Freshw. Res. 50, 1-14.

Fowler, A. J., McLeay, L., and Short, D. (2000b). Spatial variation in size and age structures and reproductive characteristics of the King George whiting (Percoidei: Sillaginidae) in South Australian waters. Mar. Freshw. Res. 51, $11-22$.

Fowler, A. J., and Short, D. A. (1996). Temporal variation in the early life-history characteristics of the King George whiting (Sillaginodes punctata) from analysis of otolith microstructure. Mar. Freshw. Res. 47, 809-818.

Gillanders, B. M. (2002). Temporal and spatial variability in elemental composition of otoliths: implications for determining stock identity and connectivity of populations. Can. J. Fish. Aquat. Sci. 59, 669-679. doi: 10.1139/f02-040

Gillanders, B. M., and Kingsford, M. J. (1996). Elements in otoliths may elucidate the contribution of estuarine recruitment to sustaining coastal reef populations of a temperate reef fish. Mar. Ecol. Prog. Ser. 141, 13-20. doi: 10.3354/ meps 141013

Ham, J. M., and Hutchinson, W. G. (2003). Spawning and Larval Rearing Research on King George Whiting (Sillaginodes punctata) Relevant to Aquaculture and Fisheries Biology. Adelaide, SA: South Australian Research and Development Institute.

Hegg, J. C., Kennedy, B. P., and Chittaro, P. (2018). What did you say about my mother? The complexities of maternally derived chemical signatures in otoliths. Can. J. Fish. Aquat. Sci. 76, 81-94. doi: 10.1139/cjfas-2017-0341

Izzo, C., Doubleday, Z. A., and Gillanders, B. M. (2016). Where do elements bind within the otoliths of fish? Mar. Freshw. Res. 67, 1072-1076.

Izzo, C., Reis-Santos, P., and Gillanders, B. M. (2018). Otolith chemistry does not just reflect environmental conditions: a meta-analytic evaluation. Fish Fish. 19, 441-454. doi: 10.1111/faf.12264

Jenkins, G. P., Black, K. P., and Hamer, P. A. (2000). Determination of spawning areas and larval advection pathways for King George whiting in southeastern Australia using otolith microstructure and hydrodynamic modelling. I. Victoria. Mar. Ecol. Prog. Ser. 199, 231-242. doi: 10.3354/ meps199231

Jenkins, G. P., Black, K. P., Wheatley, M. J., and Hatton, D. N. (1997). Temporal and spatial variability in recruitment of a temperate, seagrass-associated fish is largely determined by physical processes in the pre-and post-settlement phases. Mar. Ecol. Prog. Ser. 148, 23-35. doi: 10.3354/meps148023

Jenkins, G. P., Hamer, P. A., Kent, J. A., Kemp, J., Sherman, C., and Fowler, A. J. (2016). Spawning Sources, Movement Patterns, and Nursery Area Replenishment of Spawning Populations of King George Whiting in South-Eastern AustraliaClosing the Life History Loop. Canberra: Fisheries Research and Development Corporation.

Jones, G. P., Planes, S., and Thorrold, S. R. (2005). Coral reef fish larvae settle close to home. Curr. Biol. 15, 1314-1318. doi: 10.1016/j.cub.2005.06.061

Kailola, P., Williams, M., Stewart, P., Reichelt, R., McNee, A., and Grieve, C. (1993). Australian Fisheries Resources. Bureau of Resource Sciences and the Fisheries Research and Development Corporation Canberra, Australia. Brisbane, QLD: Imprint Limited.

Kent, J., Jenkins, G., and Sherman, C. D. (2018). Low levels of genetic structuring in King George whiting Sillaginodes punctatus across two geographic regions. J. Fish Biol. 92, 523-531. doi: 10.1111/jfb.13510

Lahaye, Y., Lambert, D., and Walters, S. (1997). Ultraviolet laser sampling and high resolution inductively coupled plasma-mass spectrometry of NIST and BCR2G glass reference materials. Geostand. Newsletter 21, 205-214. doi: 10.1111/j. 1751-908x.1997.tb00671.x

Lazartigues, A., Girard, C., Brodeur, P., Lecomte, F., Mingelbier, M., and Sirois, P. (2017). Otolith microchemistry to identify sources of larval yellow perch in a fluvial lake: an approach towards freshwater fish management. Can. J. Fish. Aquat. Sci. 75, 474-487. doi: 10.1139/cjfas-20160289
Lazartigues, A. V., Plourde, S., Dodson, J. J., Morissette, O., Ouellet, P., and Sirois, P. (2016). Determining natal sources of capelin in a boreal marine park using otolith microchemistry. ICES J. Mar. Sci. 73, 2644-2652. doi: 10.1093/icesjms/ fsw104

Lazartigues, A. V., Sirois, P., and Savard, D. (2014). LA-ICP-MS analysis of small samples: carbonate reference materials and larval fish otoliths. Geostand. Geoanal. Res. 38, 225-240.

Leis, J. M., Siebeck, U., and Dixson, D. L. (2011). How Nemo finds home: the neuroecology of dispersal and of population connectivity in larvae of marine fishes. Integr. Comp. Biol. 51, 826-843. doi: 10.1093/icb/icr004

Loeppky, A. R., Purchase, C. F., and Davoren, G. K. (2018). Chemical signatures in embryonic otoliths of capelin, Mallotus villosus: influence of family and environmental conditions. J. Exp. Mar. Biol. Ecol. 498, 25-31. doi: 10.1016/j. jembe.2017.10.007

Ludsin, S. A., Fryer, B. J., and Gagnon, J. E. (2006). Comparison of solution-based versus laser ablation inductively coupled plasma mass spectrometry for analysis of larval fish otolith microelemental composition. Trans. Am. Fish. Soc. 135, 218-231. doi: 10.1577/t04-165.1

Macdonald, J. I., Shelley, J. M. G., and Crook, D. A. (2008). A method for improving the estimation of natal chemical signatures in otoliths. Trans. Am. Fish. Soc. 137, 1674-1682. doi: 10.1577/t07-249.1

McLeay, L., Doubell, M., Roberts, S., Dixon, C., Andreacchio, L., James, C., et al. (2016). A biophysical model to assess the trade-off between larval recruitment and catch in southern Australia's largest prawn fishery. Fish. Oceanogr. 25, 164-182. doi: 10.1111/fog.12143

Middleton, J. F., and Bye, J. A. (2007). A review of the shelf-slope circulation along Australia’s southern shelves: Cape Leeuwin to Portland. Prog. Oceanogr. 75, 1-41. doi: 10.1016/j.pocean.2007.07.001

Mobsby, D. (2018). Australian Fisheries and Aquaculture Statistics 2017. Fisheries Research and Development Corporation Project 2018-134, Book 95. Canberra: ABARES.

Murua, H., and Saborido-Rey, F. (2003). Female reproductive strategies of marine fish species of the North Atlantic. J. Northwest Atlantic Fish. Sci. 33, 23-31. doi: 10.2960/j.v33.a2

Norcross, B. L., and Shaw, R. F. (1984). Oceanic and estuarine transport of fish eggs and larvae: a review. Trans. Am. Fish. Soc. 113, 153-165. doi: 10.1577/ 1548-8659(1984)113<153:oaetof>2.0.co;2

Oxley, A. P., Catalano, S. R., Wos-Oxley, M. L., Westlake, E. L., Grammer, G. L., and Steer, M. A. (2017). Using in situ hybridization to expand the daily egg production method to new fish species. Mol. Ecol. Resour. 17, 1108-1121. doi: 10.1111/1755-0998.12707

Paton, C., Hellstrom, J., Paul, B., Woodhead, J., and Hergt, J. (2011). Iolite: freeware for the visualisation and processing of mass spectrometric data. J. Anal. Atomic Spectr. 26, 2508-2518.

Petrusevics, P. (1993). SST fronts in inverse estuaries, South Australiaindicators of reduced gulf-shelf exchange. Mar. Freshw. Res. 44, 305-323.

Petrusevics, P., Bye, J., Luick, J., and Teixeira, C. E. (2011). Summer sea surface temperature fronts and elevated chlorophyll-a in the entrance to Spencer Gulf, South Australia. Cont. Shelf Res. 31, 849-856. doi: 10.1016/j.csr.2011. 02.009

Reis-Santos, P., Gillanders, B. M., Tanner, S. E., Vasconcelos, R. P., Elsdon, T. S., and Cabral, H. N. (2012). Temporal variability in estuarine fish otolith elemental fingerprints: implications for connectivity assessments. Estuarine Coast. Shelf Sci. 112, 216-224. doi: 10.1016/j.ecss.2012.07.027

Rogers, T. A., Fowler, A. J., Steer, M. A., and Gillanders, B. M. (2019a). Resolving the early life history of King George whiting (Sillaginodes punctatus: Perciformes) using otolith microstructure and trace element chemistry. Mar. Freshw. Res. 70:16.

Rogers, T. A., Fowler, A. J., Steer, M. A., and Gillanders, B. M. (2019b). Spatial connectivity during the early life history of a temperate marine fish inferred from otolith microstructure and geochemistry. Estuarine Coast. Shelf Sci. $227,12$.

Ruttenberg, B. I., Hamilton, S. L., Hickford, M. J., Paradis, G. L., Sheehy, M. S., Standish, J. D., et al. (2005). Elevated levels of trace elements in cores of otoliths and their potential for use as natural tags. Mar. Ecol. Prog. Ser. 297, 273-281. doi: $10.3354 /$ meps 297273 
Ruttenberg, B. I., and Warner, R. R. (2006). Spatial variation in the chemical composition of natal otoliths from a reef fish in the Galapagos Islands. Mar. Ecol. Prog. Ser. 328, 225-236. doi: 10.3354/meps328225

Sadovy, Y. (2001). The threat of fishing to highly fecund fishes. J. Fish Biol. 59, 90-108. doi: 10.1006/jfbi.2001.1760

Schaffler, J. J., Reiss, C. S., and Jones, C. M. (2009). Spatial variation in otolith chemistry of Atlantic croaker larvae in the Mid-Atlantic Bight. Mar. Ecol. Prog. Ser. 382, 185-195.

Standish, J. D., Sheehy, M., and Warner, R. R. (2008). Use of otolith natal elemental signatures as natural tags to evaluate connectivity among opencoast fish populations. Mar. Ecol. Prog. Ser. 356, 259-268. doi: 10.3354/meps0 7244

Standish, J. D., White, J. W., and Warner, R. R. (2011). Spatial pattern of natal signatures in the otoliths of juvenile kelp rockfish along the Californian coast. Mar. Ecol. Prog. Ser. 437, 279-290. doi: 10.3354/meps 09241

Starrs, D., Davis, J. T., Schlaefer, J., Ebner, B. C., Eggins, S. M., and Fulton, C. J. (2013). Maternally transmitted isotopes and their effects on larval fish: a validation of dual isotopic marks within a meta-analysis context. Can. J. Fish. Aquat. Sci. 71, 387-397. doi: 10.1139/cjfas-2013-0416

Steer, M., Fowler, A., McGarvey, R., Feenstra, J., Smart, J., Rogers, P., et al. (2018). Assessment of the South Australian Marine Scalefish Fishery in 2016. Report to PIRSA Fisheries and Aquaculture, SARDI Publication no F2017/000427-1, SARDI Research Report Series no 974. Adelaide, SA: South Australian Research and Development Institute.

Swearer, S. E., Caselle, J. E., Lea, D. W., and Warner, R. R. (1999). Larval retention and recruitment in an island population of a coral-reef fish. Nature 402, 799-803.

Swearer, S. E., Shima, J. S., Hellberg, M. E., Thorrold, S. R., Jones, G. P., Robertson, D. R., et al. (2002). Evidence of self-recruitment in demersal marine populations. Bull. Mar. Sci. 70, 251-271.

Tanner, S. E., Reis-Santos, P., and Cabral, H. N. (2016). Otolith chemistry in stock delineation: a brief overview, current challenges and future prospects. Fish. Res. 173, 206-213. doi: 10.1016/j.fishres.2015.07.019

Tanner, S. E., Vasconcelos, R. P., Cabral, H. N., and Thorrold, S. R. (2012). Testing an otolith geochemistry approach to determine population structure and movements of European hake in the northeast Atlantic Ocean and Mediterranean Sea. Fish. Res. 125, 198-205. doi: 10.1016/j.fishres.2012. 02.013

Thomas, O. R., Ganio, K., Roberts, B. R., and Swearer, S. E. (2017). Trace elementprotein interactions in endolymph from the inner ear of fish: implications for environmental reconstructions using fish otolith chemistry. Metallomics 9 , 239-249. doi: 10.1039/c6mt00189k
Thorrold, S. R., Jones, G. P., Hellberg, M. E., Burton, R. S., Swearer, S. E., Neigel, J. E., et al. (2002). Quantifying larval retention and connectivity in marine populations with artificial and natural markers. Bull. Mar. Sci. 70, 291-308.

Thorrold, S. R., Jones, G. P., Planes, S., and Hare, J. A. (2006). Transgenerational marking of embryonic otoliths in marine fishes using barium stable isotopes. Can. J. Fish. Aquat. Sci. 63, 1193-1197. doi: 10.1139/f06-048

Thorrold, S. R., Zacherl, D. C., and Levin, L. A. (2007). Population connectivity and larval dispersal: using geochemical signatures in calcified structures. Oceanography 20, 80-89. doi: 10.5670/oceanog.2007.31

Titus, K., Mosher, J. A., and Williams, B. K. (1984). Chance-corrected classification for use in discriminant analysis: ecological applications. Am. Midl. Nat. $111,1-7$.

Tzadik, O. E., Curtis, J. S., Granneman, J. E., Kurth, B. N., Pusack, T. J., Wallace, A. A., et al. (2017). Chemical archives in fishes beyond otoliths: a review on the use of other body parts as chronological recorders of microchemical constituents for expanding interpretations of environmental, ecological, and life-history changes. Limnol. Oceanogr. Methods 15, 238-263. doi: 10.1002/ lom3.10153

Walther, B. D., and Thorrold, S. R. (2006). Water, not food, contributes the majority of strontium and barium deposited in the otoliths of a marine fish. Mar. Ecol. Prog. Ser. 311, 125-130. doi: 10.3354/meps311125

Warner, R. R., Swearer, S. E., Caselle, J. E., Sheehy, M., and Paradis, G. (2005). Natal trace-elemental signatures in the otoliths of an open-coast fish. Limnol. Oceanogr. 50, 1529-1542. doi: 10.4319/lo.2005.50.5.1529

Watai, M., Hiraoka, Y., Ishihara, T., Yamasaki, I., Ota, T., Ohshimo, S., et al. (2018). Comparative analysis of the early growth history of Pacific bluefin tuna Thunnus orientalis from different spawning grounds. Mar. Ecol. Prog. Ser. 607, 207-220. doi: 10.3354/meps12807

Yoshinaga, J., Nakama, A., Morita, M., and Edmonds, J. S. (2000). Fish otolith reference material for quality assurance of chemical analyses. Mar. Chem. 69, 91-97. doi: 10.1016/s0304-4203(99)00098-5

Conflict of Interest: The authors declare that the research was conducted in the absence of any commercial or financial relationships that could be construed as a potential conflict of interest.

Copyright (c) 2019 Rogers, Fowler, Steer and Gillanders. This is an open-access article distributed under the terms of the Creative Commons Attribution License (CC BY). The use, distribution or reproduction in other forums is permitted, provided the original author(s) and the copyright owner(s) are credited and that the original publication in this journal is cited, in accordance with accepted academic practice. No use, distribution or reproduction is permitted which does not comply with these terms. 